\title{
Bioactive Isoprenoid-derived Natural Products from a Dongsha Atoll Soft Coral Sinularia erecta
}

\author{
Chiung-Yao Huang, ${ }^{\dagger, \diamond}$ Yen-Ju Tseng, ${ }^{\dagger, \diamond}$ Uvarani Chokkalingam, ${ }^{\dagger}$ Tsong-Long Hwang, ${ }^{\ddagger}$ Chi-Hsin Hsu, ${ }^{\dagger}$ Chang-Feng Dai, ${ }^{\S}$ \\ Ping-Jyun Sung ${ }^{\dagger, \perp}$ and Jyh-Horng Sheu ${ }^{*}, \dagger, \|, \nabla, \bigcirc$
}

${ }^{\dagger}$ Department of Marine Biotechnology and Resources, National Sun Yat-sen University, Kaohsiung 804, Taiwan

*aduate Institute of Natural Products, College of Medicine, Chang Gung University; Research Center for Industry of Human Ecology and Graduate Institute of Health Industry Technology, Chang Gung University of Science and Technology; Department of Anesthesiology, Chang Gung Memorial Hospital, Taoyuan 333, Taiwan

${ }^{\S}$ Institute of Oceanography National Taiwan University, Taipei 106, Taiwan

${ }^{\perp}$ National Museum of Marine Biology \& Aquarium, Pingtung 944, Taiwan

"Institute of Natural Products, Kaohsiung Medical University, Kaohsiung 807, Taiwan

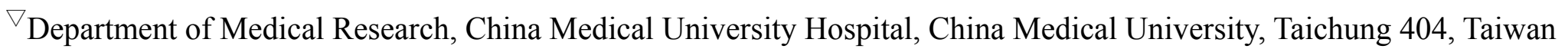

${ }^{\circ}$ Frontier Center for Ocean Science and Technology, National Sun Yat-sen University, Kaohsiung 804, Taiwan

*To whom correspondence should be addressed. Tel.: +886-7-5252000 ext. 5030, Fax: +886-7-5255020.

E-mail: sheu@mail.nsysu.edu.tw.

${ }^{\diamond}$ These authors contributed equally to this work. 


\begin{tabular}{|c|c|c|c|c|c|}
\hline No & Content & page & No & Content & page \\
\hline S1-1 & ${ }^{1} \mathrm{H}$ NMR spectrum $(400 \mathrm{MHz})$ of compound $\mathbf{1}$ in $\mathrm{CDCl}_{3}$. & 3 & S3-7 & NOESY spectrum $(500 \mathrm{MHz})$ of compound 3 in $\mathrm{CDCl}_{3}$. & 23 \\
\hline S1-2 & ${ }^{13} \mathrm{C}$ NMR spectrum $(100 \mathrm{MHz})$ of compound 1 in $\mathrm{CDCl}_{3}$. & 4 & S4-1 & ${ }^{1} \mathrm{H}$ NMR spectrum $(500 \mathrm{MHz})$ of compound 4 in $\mathrm{CDCl}_{3}$. & 24 \\
\hline S1-3 & DEPT spectra $(100 \mathrm{MHz})$ of compound $\mathbf{1}$ in $\mathrm{CDCl}_{3}$. & 5 & S4-2 & ${ }^{13} \mathrm{C}$ NMR spectrum $(125 \mathrm{MHz})$ of compound 4 in $\mathrm{CDCl}_{3}$. & 25 \\
\hline S1-4 & HSQC spectrum (400 MHz) of compound 1 in $\mathrm{CDCl}_{3}$. & 6 & S4-3 & DEPT spectra $(125 \mathrm{MHz})$ of compound 4 in $\mathrm{CDCl}_{3}$. & 26 \\
\hline S1-5 & COSY spectrum (400 MHz) of compound 1 in $\mathrm{CDCl}_{3}$. & 7 & S4-4 & HSQC spectrum (500 MHz) of compound 4 in $\mathrm{CDCl}_{3}$. & 27 \\
\hline S1-6 & HMBC spectrum $(400 \mathrm{MHz})$ of compound 1 in $\mathrm{CDCl}_{3}$. & 8 & S4-5 & COSY spectrum $(500 \mathrm{MHz})$ of compound 4 in $\mathrm{CDCl}_{3}$. & 28 \\
\hline S1-7 & NOESY spectrum (400 MHz) of compound 1 in $\mathrm{CDCl}_{3}$. & 9 & S4-6 & HMBC spectrum ( $500 \mathrm{MHz}$ ) of compound 4 in $\mathrm{CDCl}_{3}$. & 29 \\
\hline S2-1 & ${ }^{1} \mathrm{H}$ NMR spectrum $\left(400 \mathrm{MHz}\right.$ ) of compound 2 in $\mathrm{CDCl}_{3}$. & 10 & S4-7 & NOESY spectrum $(500 \mathrm{MHz})$ of compound 4 in $\mathrm{CDCl}_{3}$. & 30 \\
\hline S2-2 & ${ }^{13} \mathrm{C}$ NMR spectrum $(100 \mathrm{MHz})$ of compound 2 in $\mathrm{CDCl}_{3}$. & 11 & S5-1 & ${ }^{1} \mathrm{H}$ and ${ }^{13} \mathrm{C}$ NMR spectroscopic data of 6. & 31 \\
\hline S2-3 & DEPT spectra $(100 \mathrm{MHz})$ of compound 2 in $\mathrm{CDCl}_{3}$. & 12 & S5-2 & ${ }^{1} \mathrm{H}$ NMR spectrum $(400 \mathrm{MHz})$ of compound 6 in DMSO- $d_{6}$. & 32 \\
\hline S2-4 & HSQC spectrum $(400 \mathrm{MHz})$ of compound 2 in $\mathrm{CDCl}_{3}$. & 13 & S5-3 & ${ }^{13} \mathrm{C}$ NMR spectrum $(100 \mathrm{MHz})$ of compound 6 in DMSO- $d_{6}$. & 33 \\
\hline S2-5 & COSY spectrum (400 MHz) of compound 2 in $\mathrm{CDCl}_{3}$. & 14 & S5-4 & ${ }^{1} \mathrm{H}$ NMR spectrum (400 MHz) of compound 6 in $\mathrm{CDCl}_{3}$. & 34 \\
\hline S2-6 & HMBC spectrum $(400 \mathrm{MHz})$ of compound 2 in $\mathrm{CDCl}_{3}$. & 15 & S5-5 & ${ }^{13} \mathrm{C}$ NMR spectrum $(100 \mathrm{MHz})$ of compound 6 in $\mathrm{CDCl}_{3}$. & 35 \\
\hline S2-7 & NOESY spectrum $(400 \mathrm{MHz})$ of compound 2 in $\mathrm{CDCl}_{3}$. & 16 & S5-6 & DEPT spectra $(100 \mathrm{MHz})$ of compound 6 in $\mathrm{CDCl}_{3}$. & 36 \\
\hline S3-1 & ${ }^{1} \mathrm{H}$ NMR spectrum $(500 \mathrm{MHz})$ of compound 3 in $\mathrm{CDCl}_{3}$. & 17 & S5-7 & HSQC spectrum (400 MHz) of compound 6 in $\mathrm{CDCl}_{3}$. & 37 \\
\hline S3-2 & ${ }^{13} \mathrm{C}$ NMR spectrum $(125 \mathrm{MHz})$ of compound 3 in $\mathrm{CDCl}_{3}$. & 18 & S5-8 & COSY spectrum (400 MHz) of compound 6 in $\mathrm{CDCl}_{3}$. & 38 \\
\hline S3-3 & DEPT spectra (125 MHz) of compound 3 in $\mathrm{CDCl}_{3}$. & 19 & S5-9 & HMBC spectrum (400 MHz) of compound 6 in $\mathrm{CDCl}_{3}$. & 39 \\
\hline S3-4 & HSQC spectrum (500 MHz) of compound 3 in $\mathrm{CDCl}_{3}$. & 20 & S5-10 & NOESY spectrum (400 MHz) of compound 6 in $\mathrm{CDCl}_{3}$. & 40 \\
\hline S3-5 & COSY spectrum $(500 \mathrm{MHz})$ of compound 3 in $\mathrm{CDCl}_{3}$. & 21 & S6 & Cytotoxicities of compounds 3,4 and 8 . & 41 \\
\hline S3-6 & HMBC spectrum $(500 \mathrm{MHz})$ of compound 3 in $\mathrm{CDCl}_{3}$. & 22 & & & \\
\hline
\end{tabular}




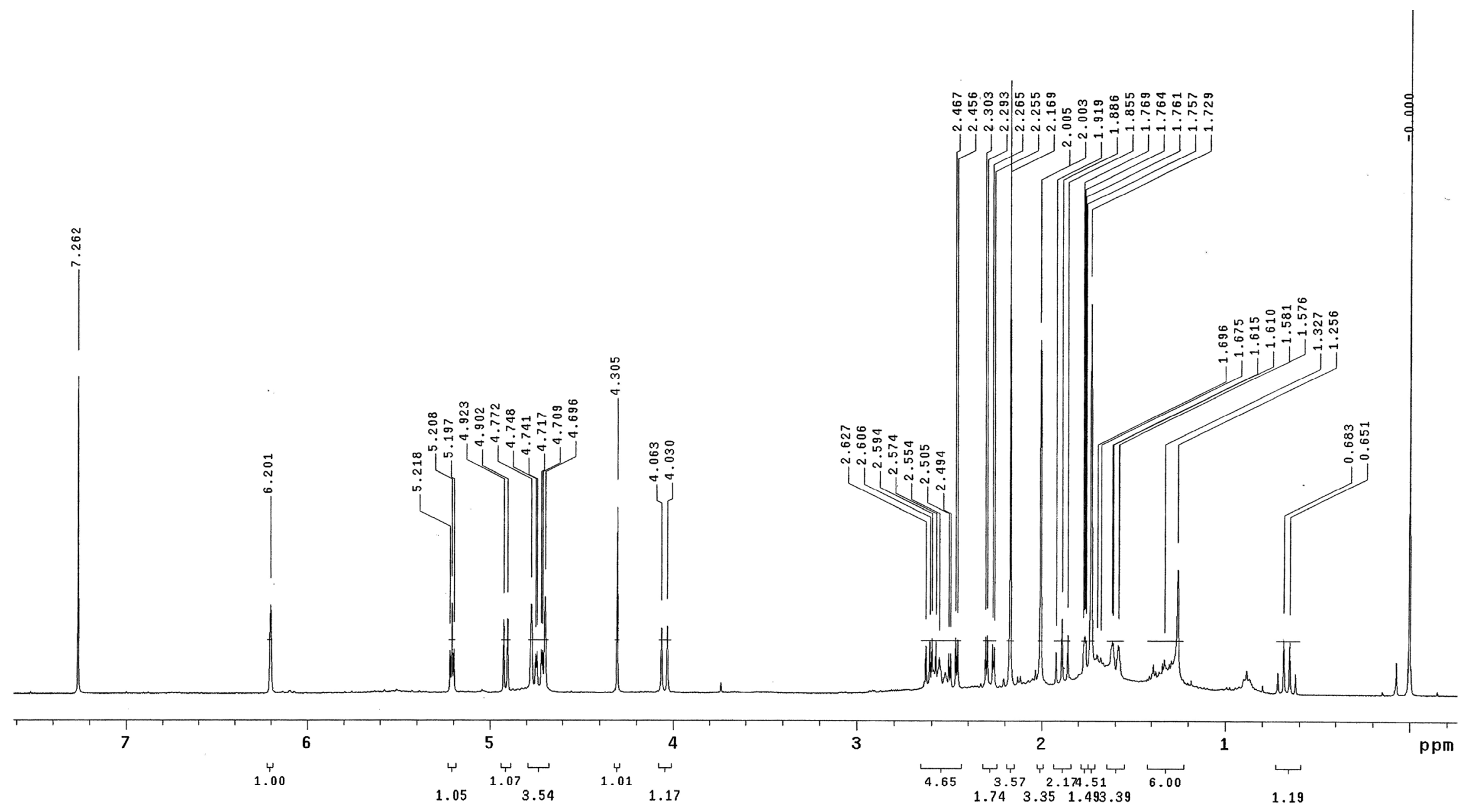

Figure S1-1. ${ }^{1} \mathrm{H}$ NMR spectrum (400 MHz) of compound 1 in $\mathrm{CDCl}_{3}$ 


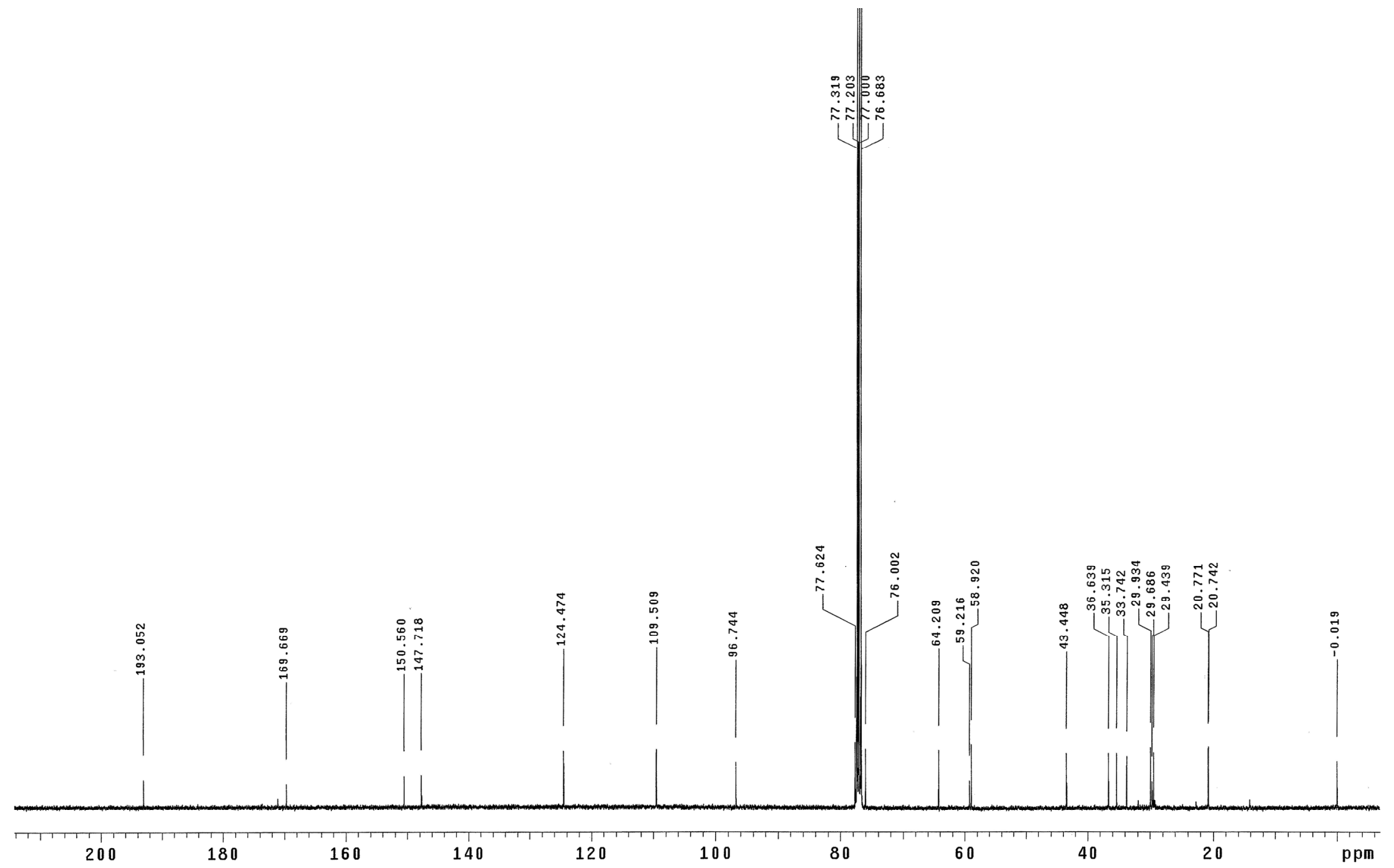

Figure S1-2. ${ }^{13} \mathrm{C}$ NMR spectrum $(100 \mathrm{MHz})$ of compound 1 in $\mathrm{CDCl}_{3}$. 

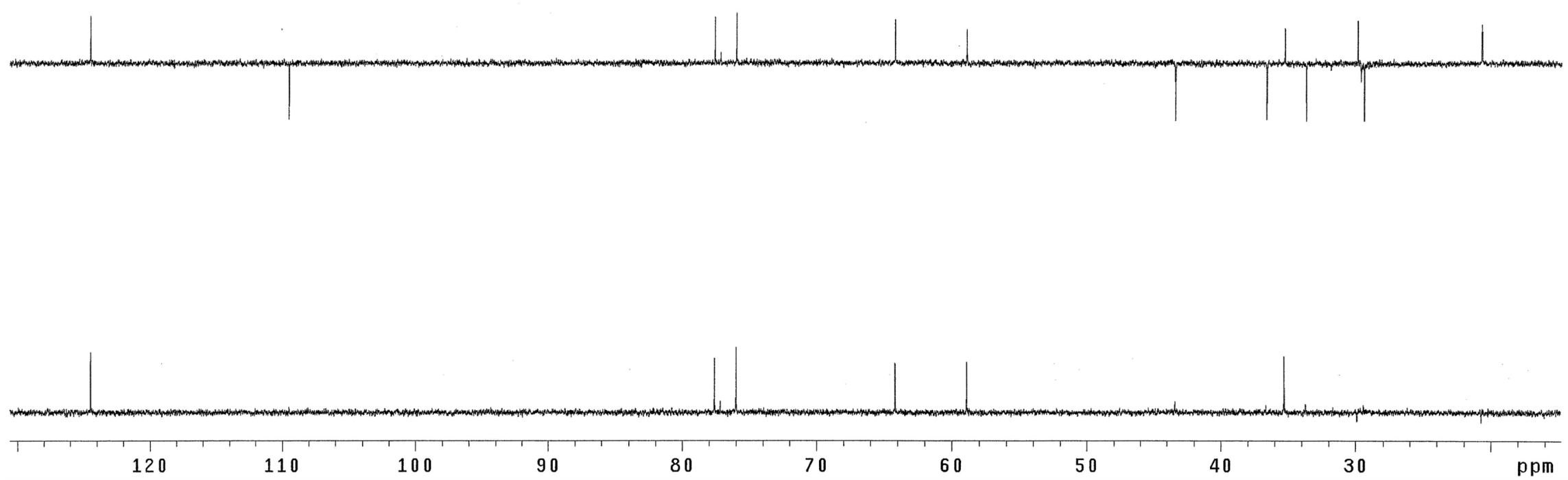

Figure S1-3. DEPT spectra (100 MHz) of compound 1 in $\mathrm{CDCl}_{3}$. 


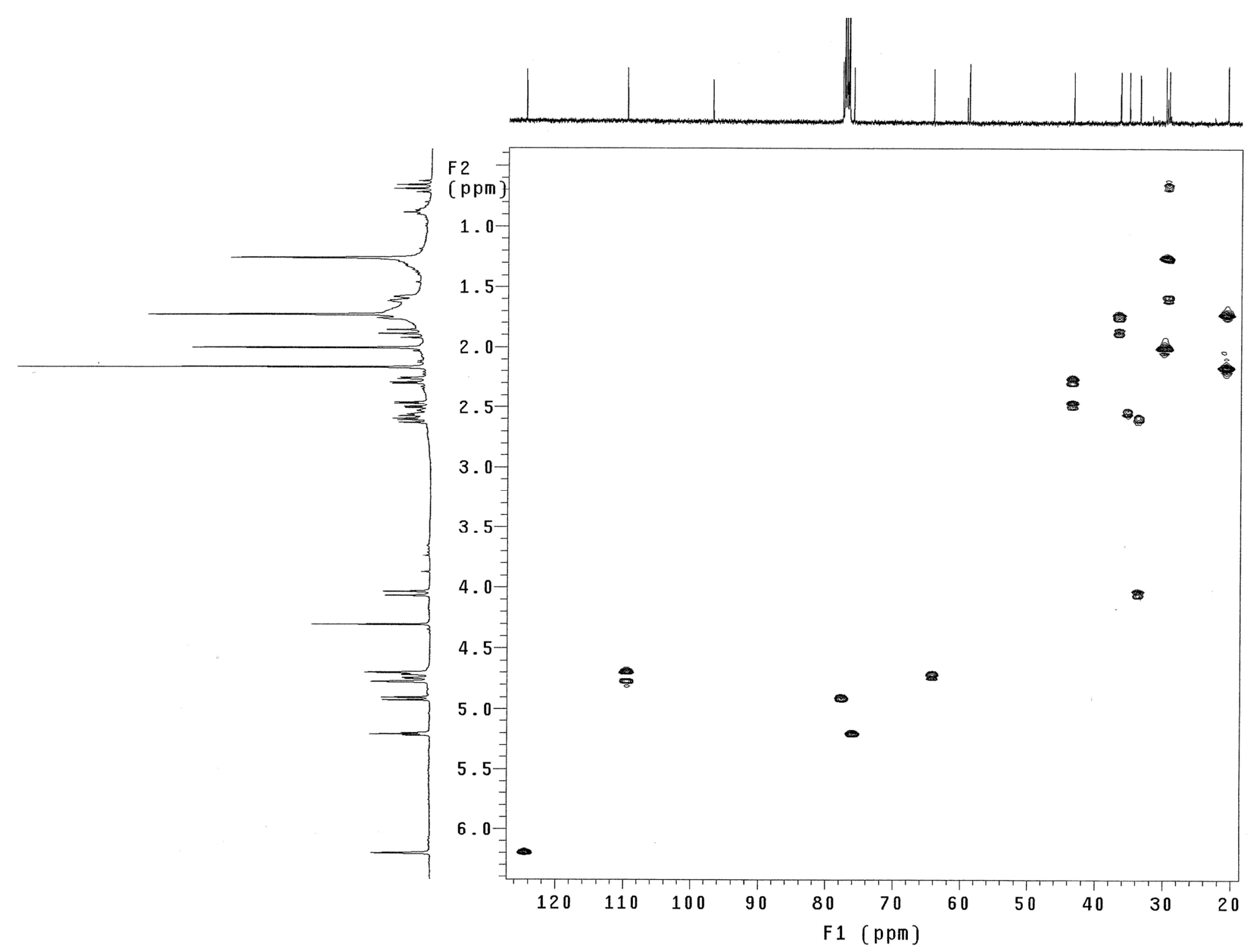

Figure S1-4. HSQC spectrum (400 MHz) of compound $\mathbf{1}$ in $\mathrm{CDCl}_{3}$. 


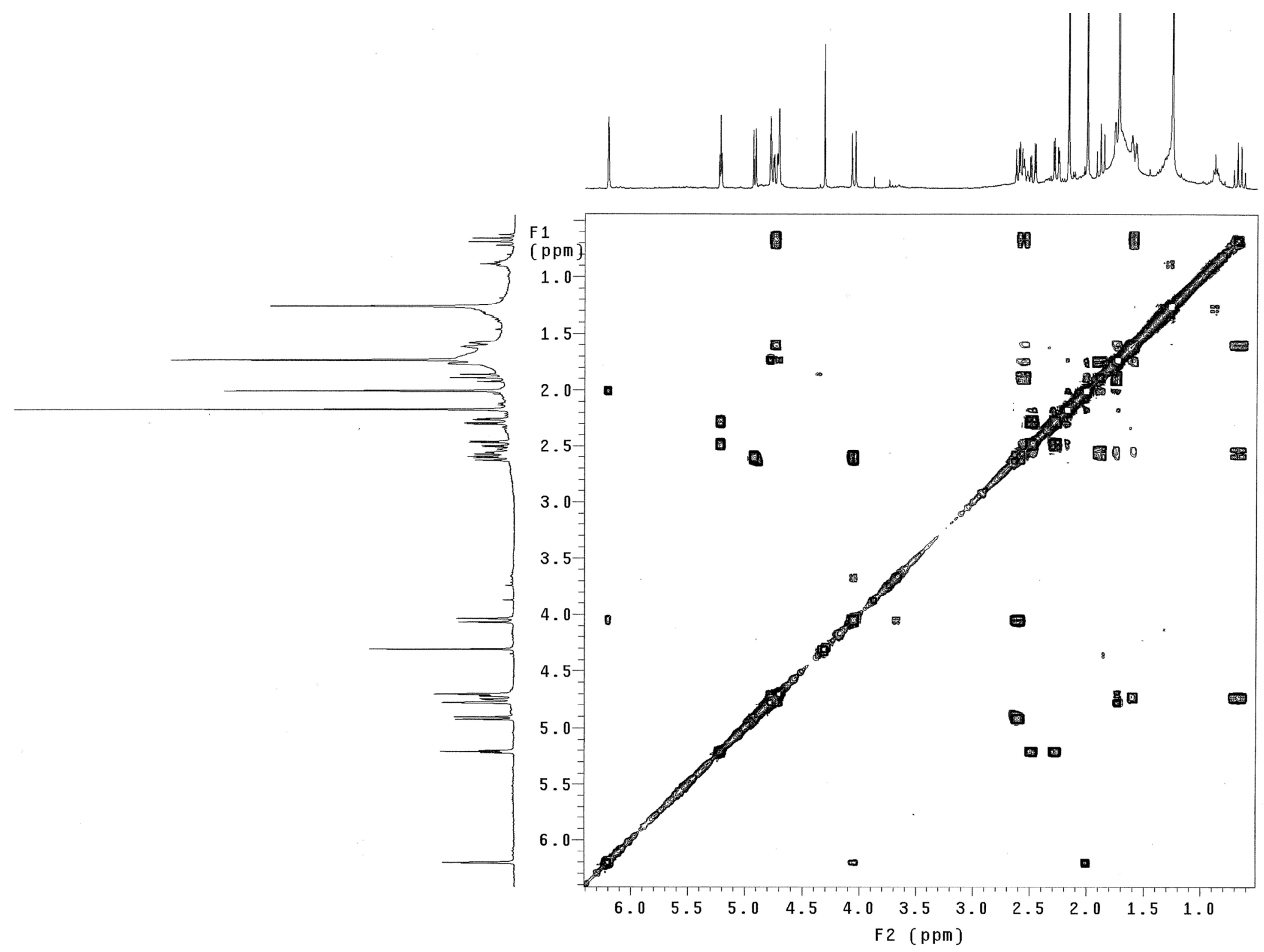

Figure S1-5. COSY spectrum (400 MHz) of compound 1 in $\mathrm{CDCl}_{3}$. 


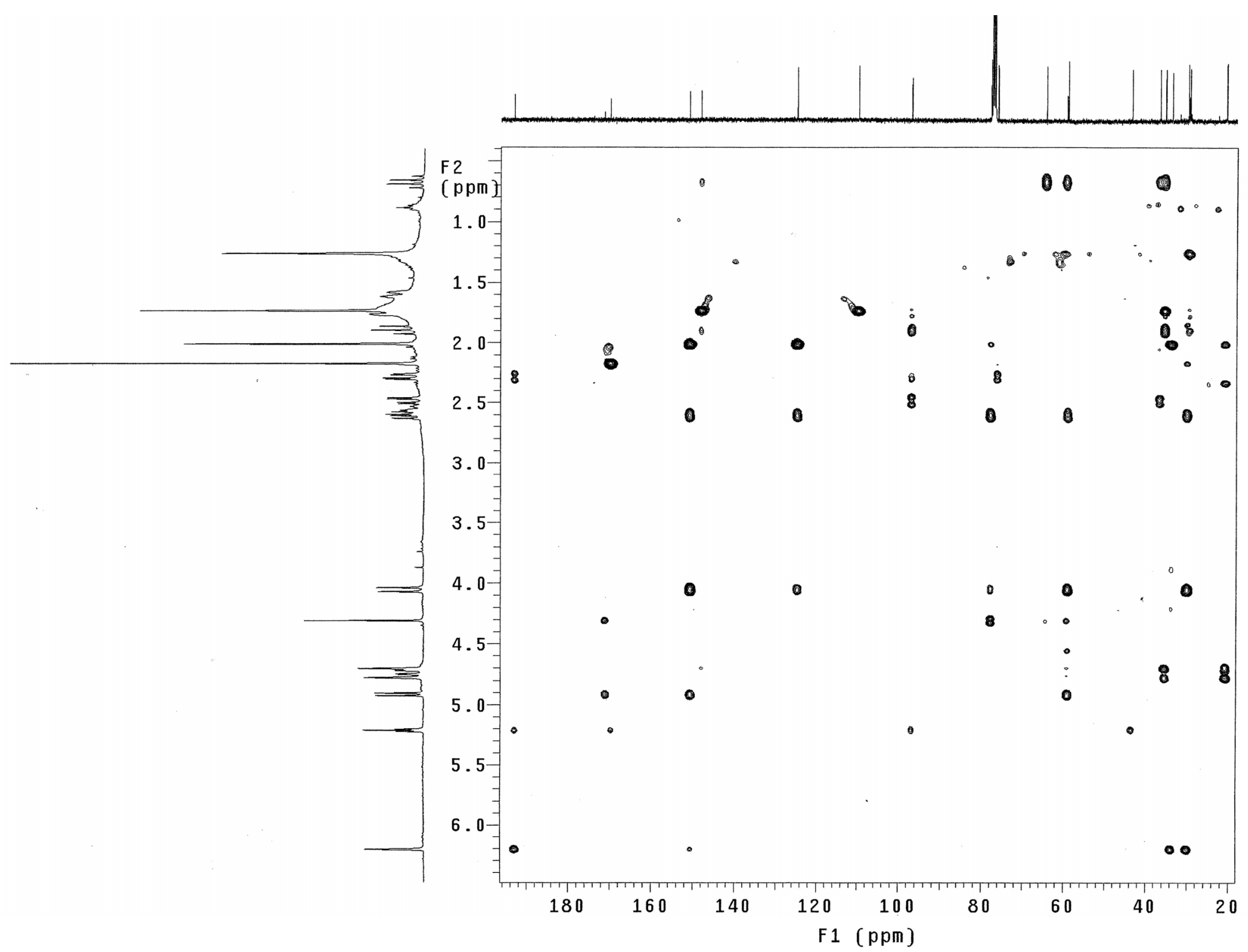

Figure S1-6. $\mathrm{HMBC}$ spectrum $(400 \mathrm{MHz})$ of compound 1 in $\mathrm{CDCl}_{3}$. 


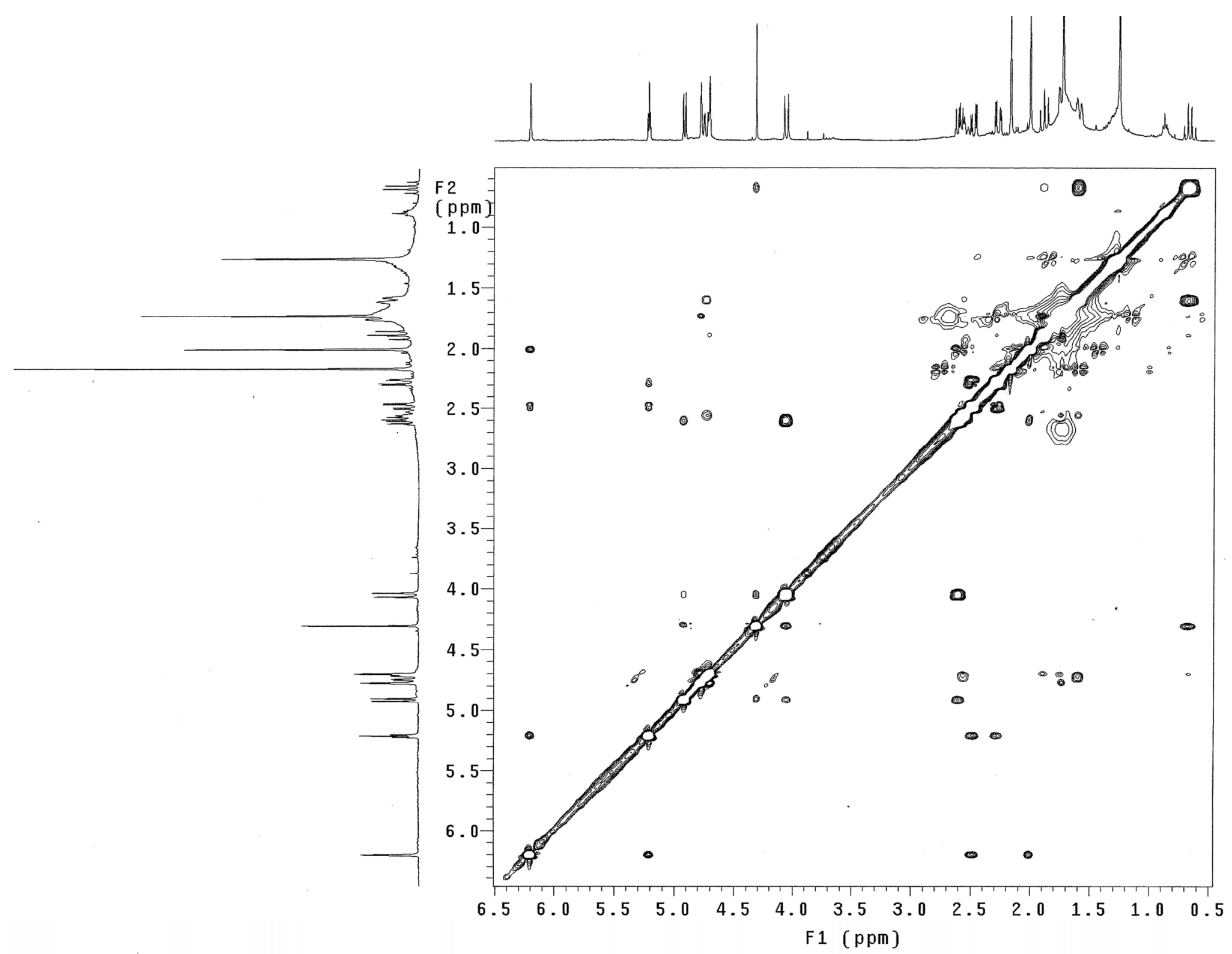

Figure S1-7. NOESY spectrum (400 MHz) of compound 1 in $\mathrm{CDCl}_{3}$. 


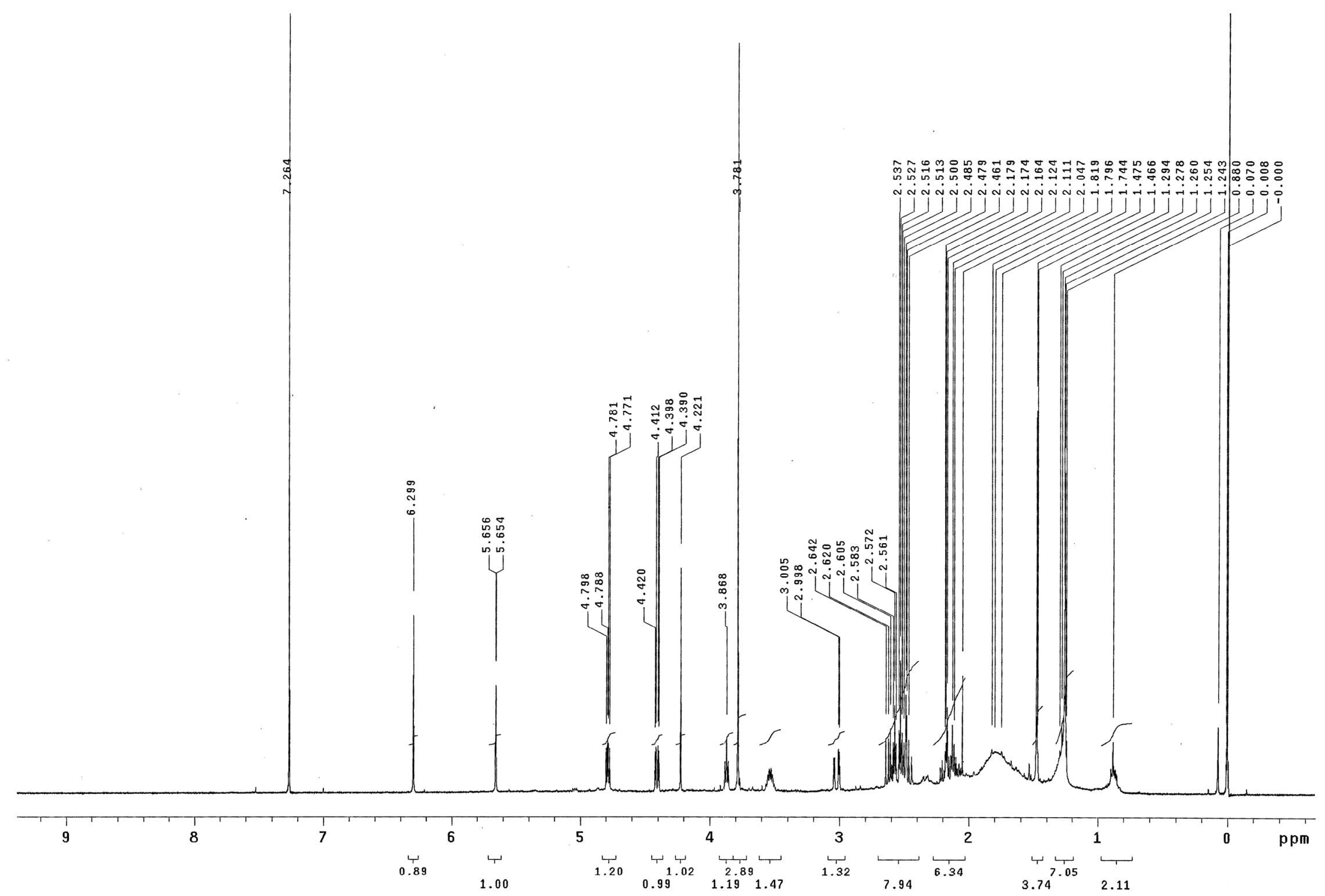

Figure S2-1. ${ }^{1} \mathrm{H}$ NMR spectrum (400 MHz) of compound 2 in $\mathrm{CDCl}_{3}$ 


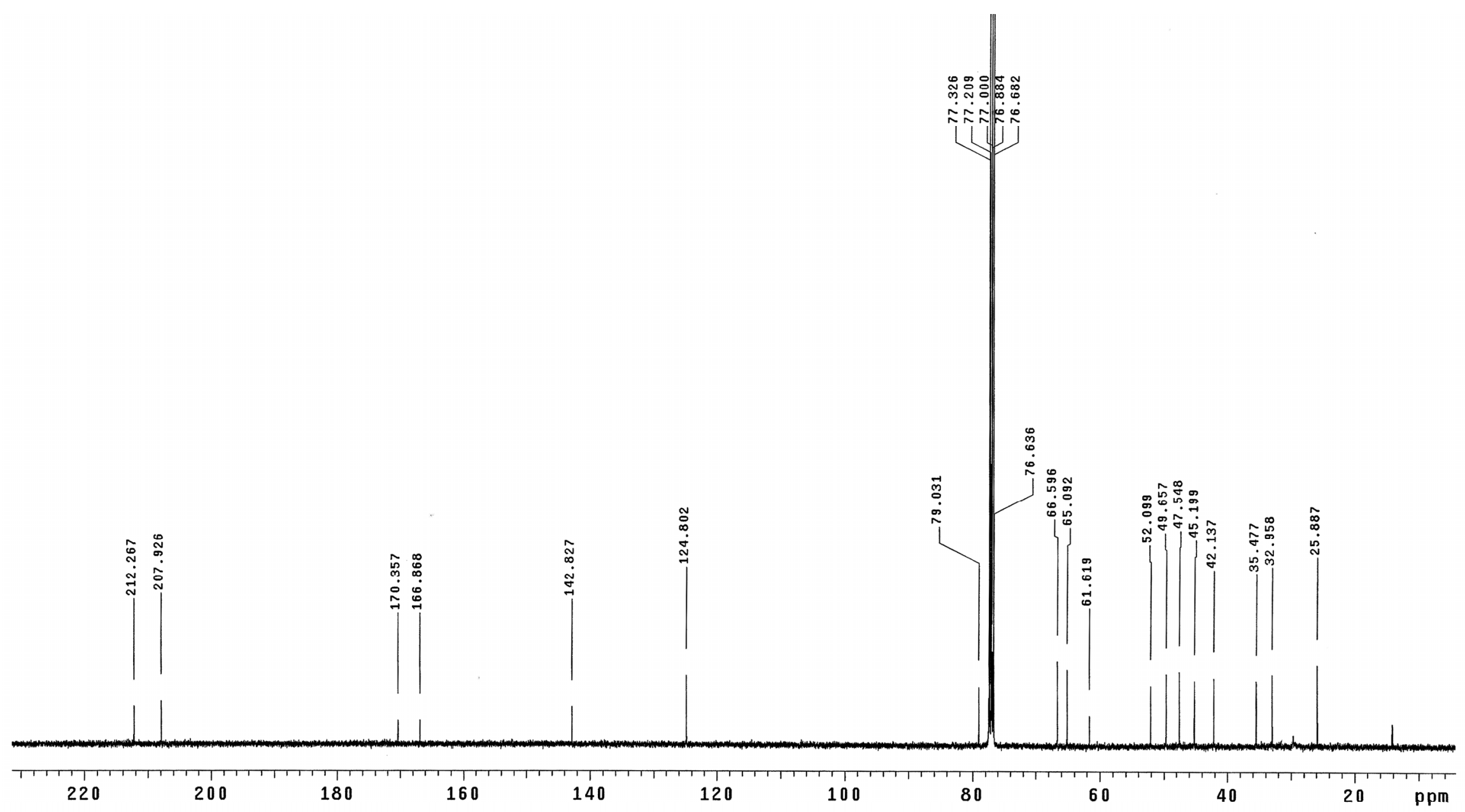

Figure S2-2. ${ }^{13} \mathrm{C}$ NMR spectrum $(100 \mathrm{MHz})$ of compound 2 in $\mathrm{CDCl}_{3}$. 

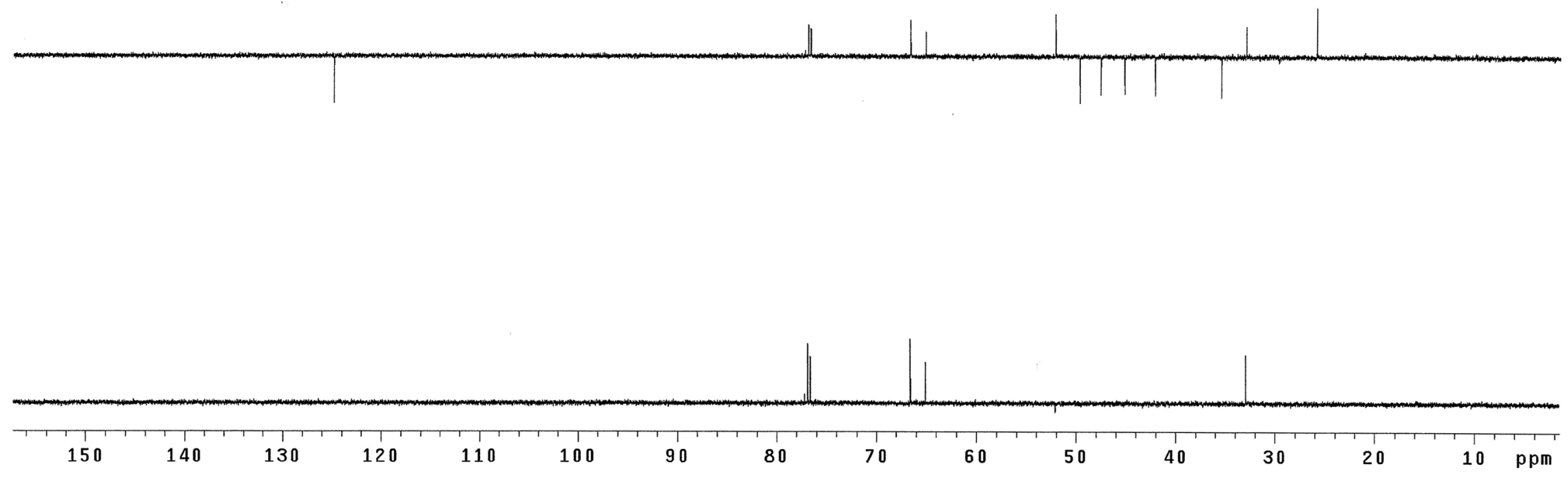

Figure S2-3. DEPT spectra $(100 \mathrm{MHz})$ of compound 2 in $\mathrm{CDCl}_{3}$ 


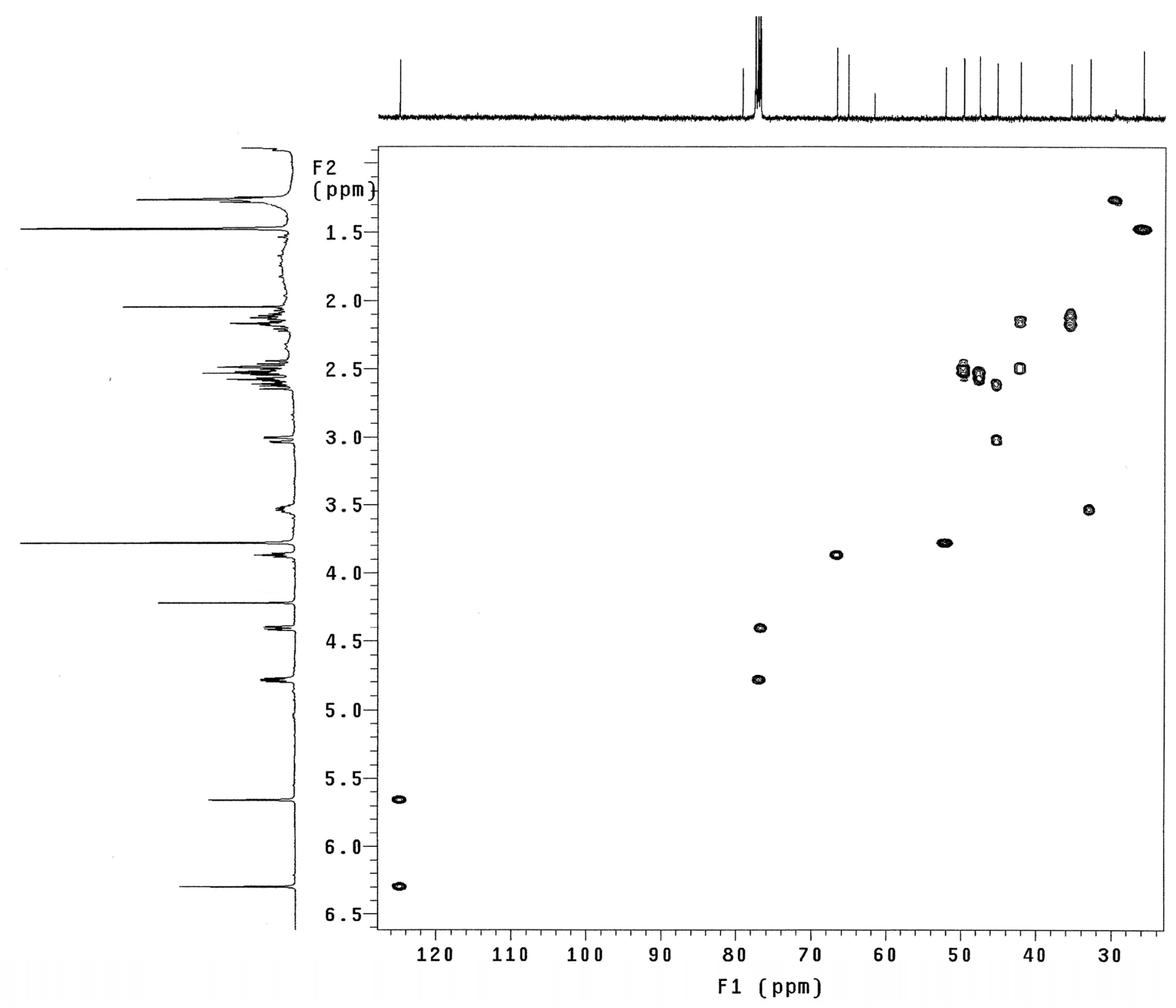

Figure S2-4. HSQC spectrum (400 MHz) of compound 2 in $\mathrm{CDCl}_{3}$. 


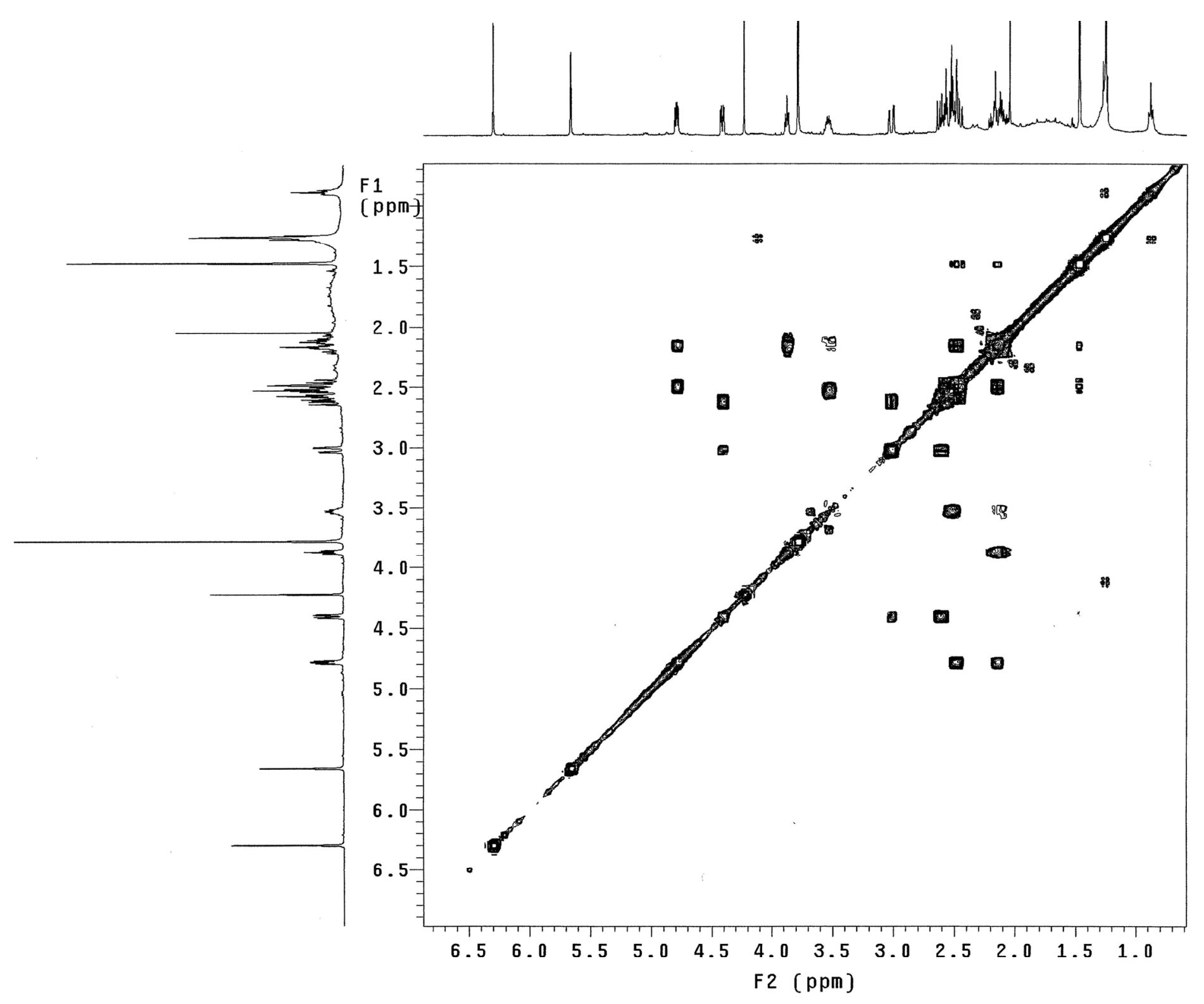

Figure S2-5. COSY spectrum (400 MHz) of compound 2 in $\mathrm{CDCl}_{3}$. 


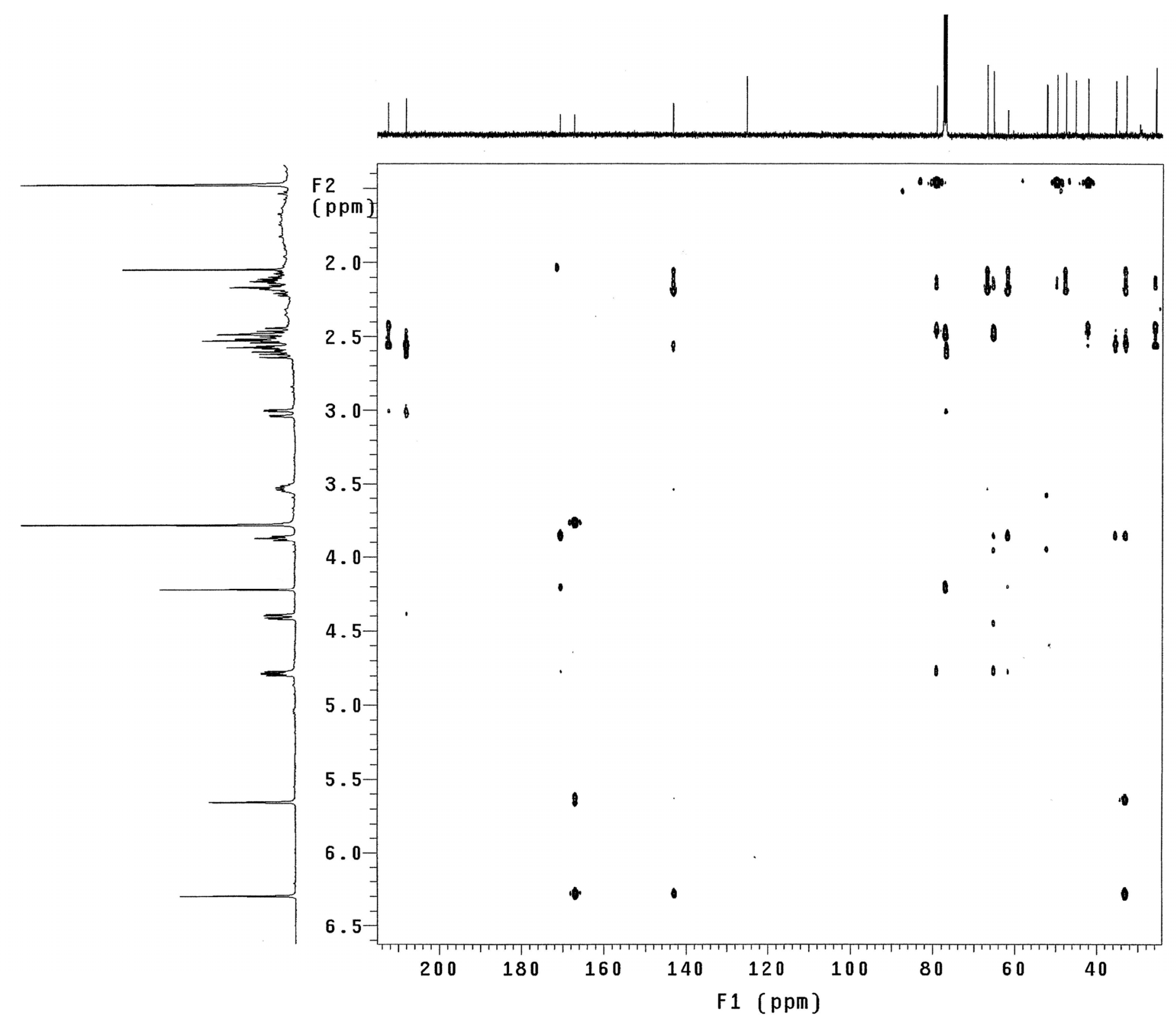

Figure S2-6. HMBC spectrum (400 MHz) of compound 2 in $\mathrm{CDCl}_{3}$. 


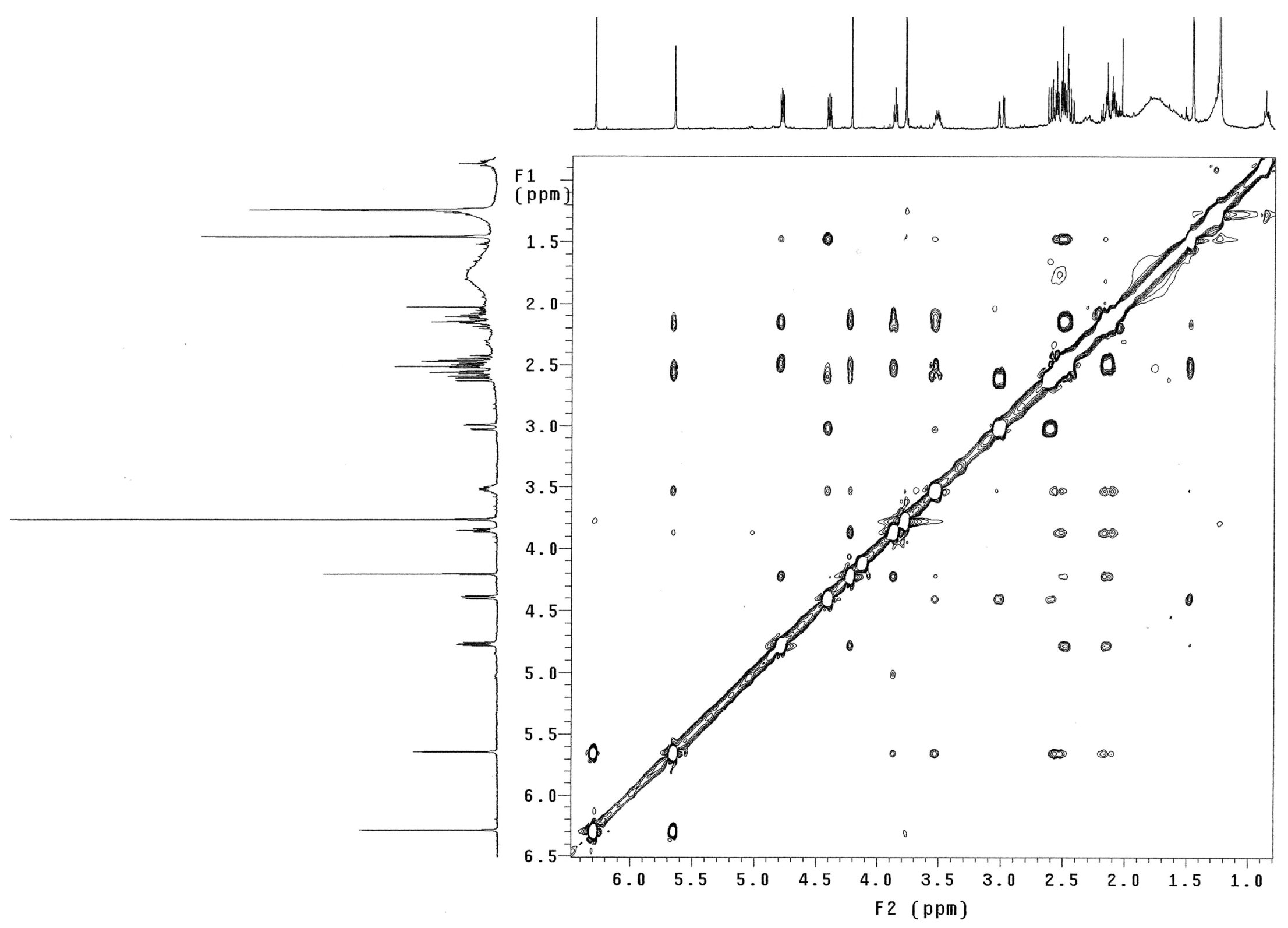

Figure S2-7. NOESY spectrum (400 MHz) of compound 2 in $\mathrm{CDCl}_{3}$. 


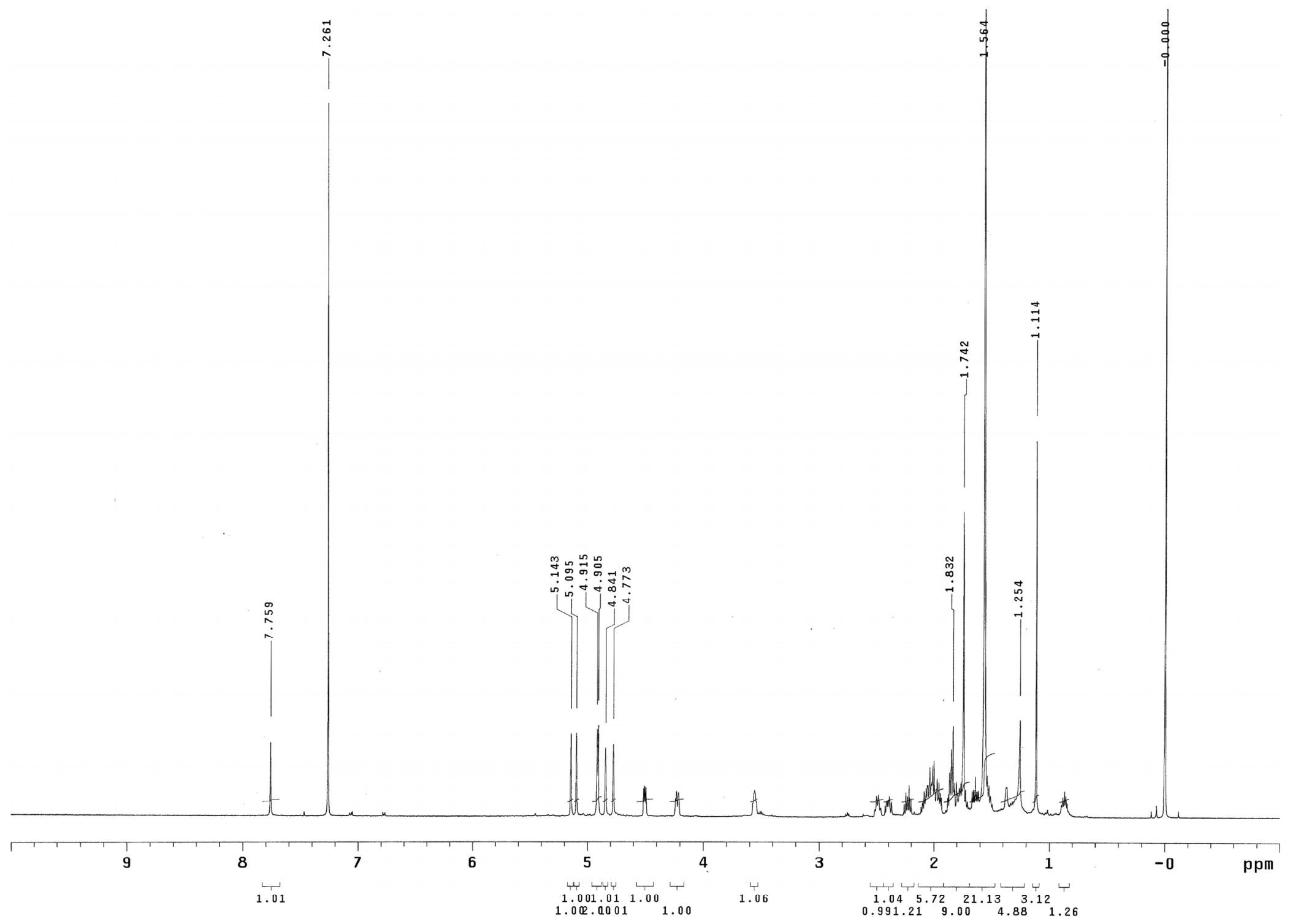

Figure S3-1. ${ }^{1} \mathrm{H}$ NMR spectrum $(500 \mathrm{MHz})$ of compound 3 in $\mathrm{CDCl}_{3}$. 


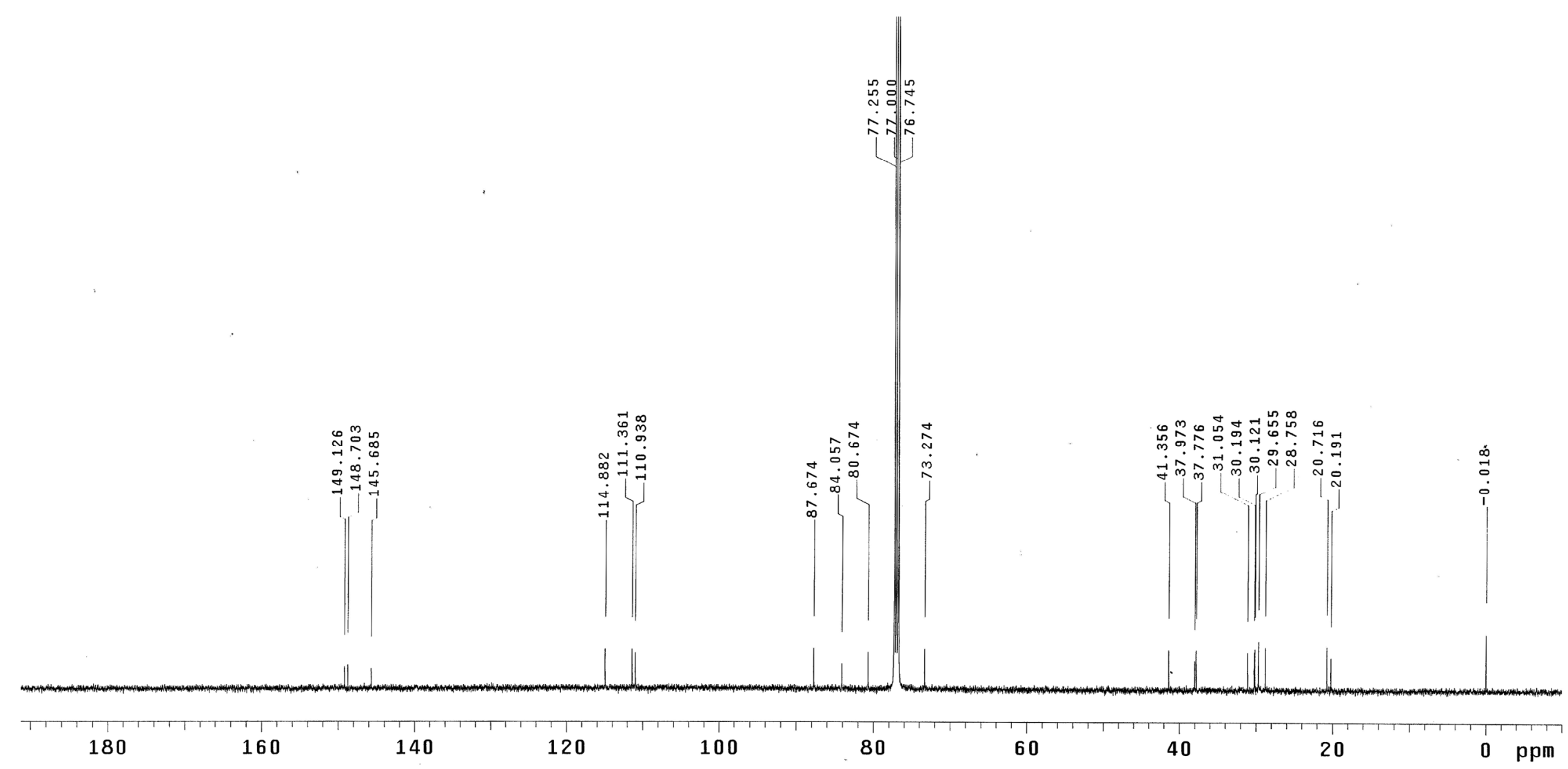

Figure S3-2. ${ }^{13} \mathrm{C}$ NMR spectrum $(125 \mathrm{MHz})$ of compound 3 in $\mathrm{CDCl}_{3}$. 


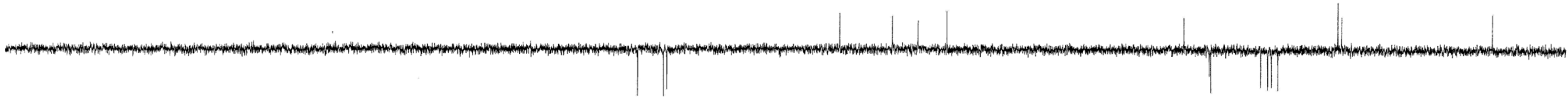

$\mathrm{CH}$ carbons

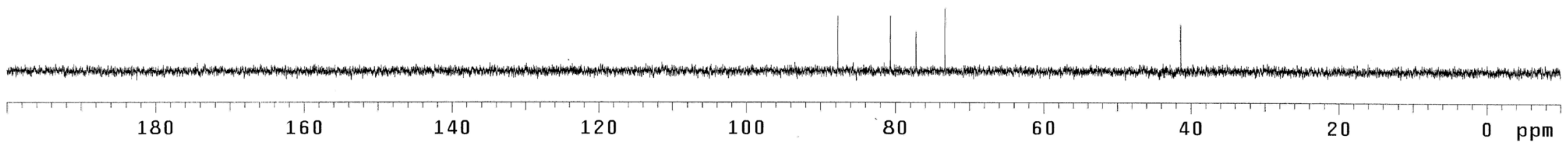

Figure S3-3. DEPT spectra (125 MHz) of compound 3 in $\mathrm{CDCl}_{3}$. 


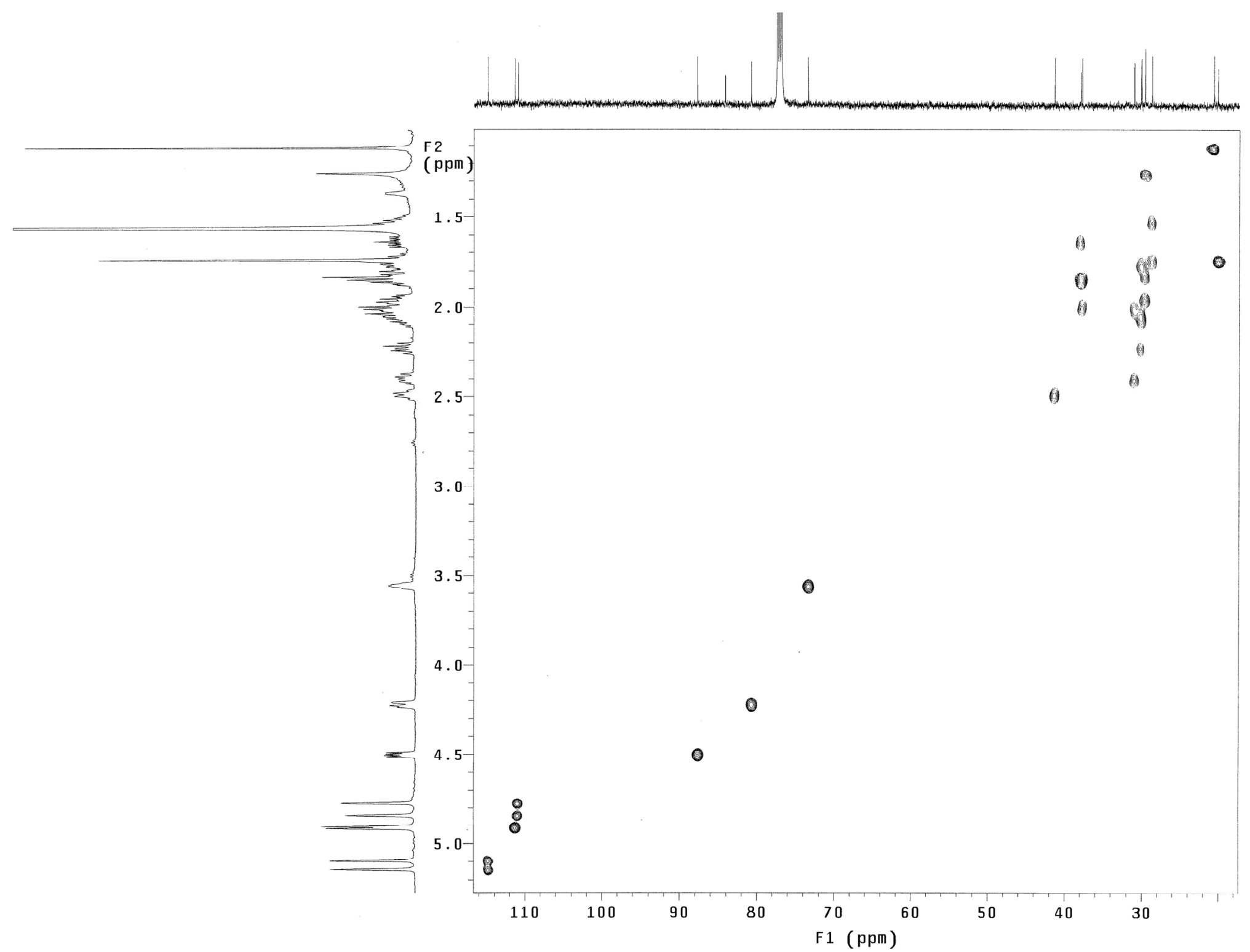

Figure S3-4. HSQC spectrum (500 MHz) of compound 3 in $\mathrm{CDCl}_{3}$. 


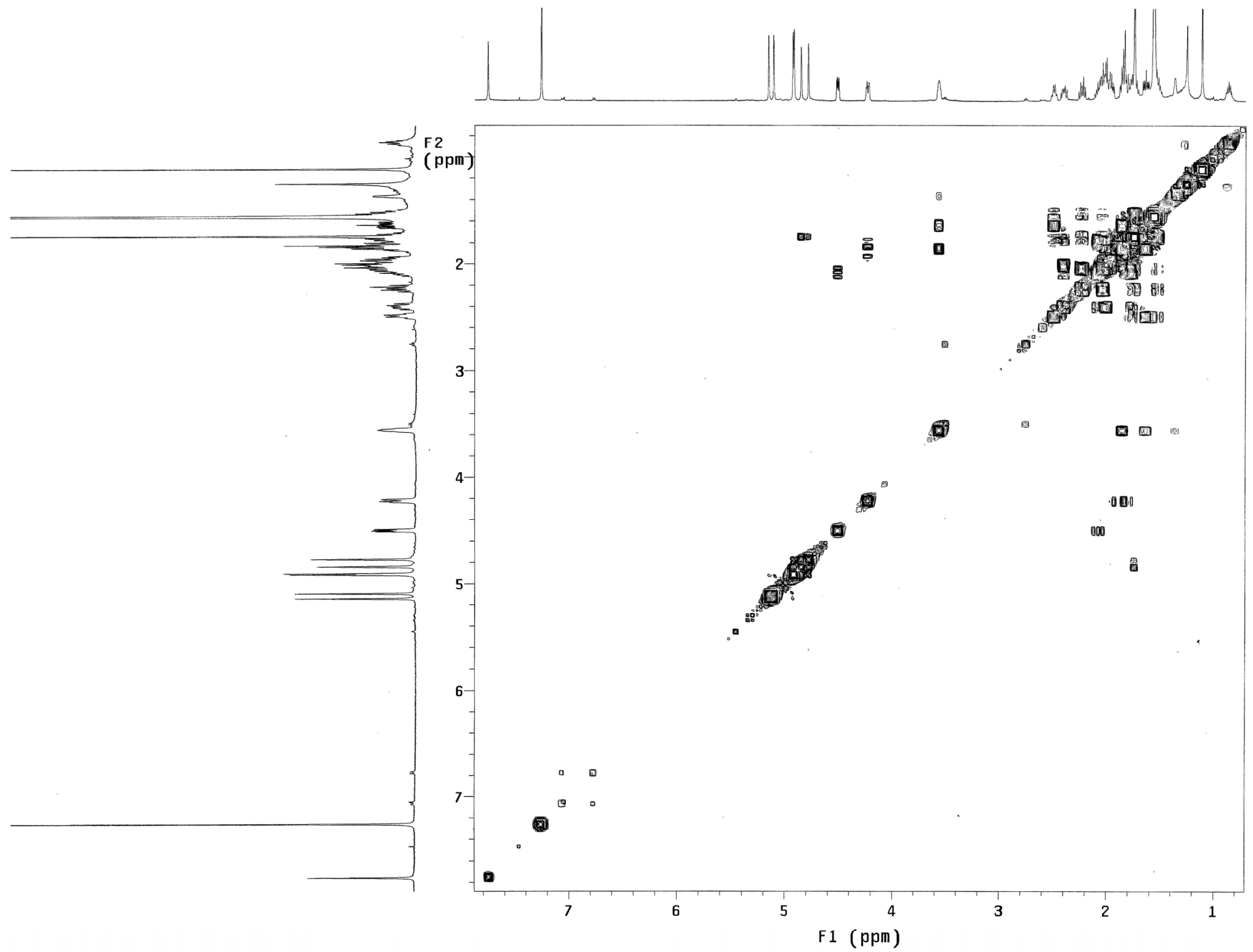

Figure S3-5. COSY spectrum (500 MHz) of compound 3 in $\mathrm{CDCl}_{3}$. 


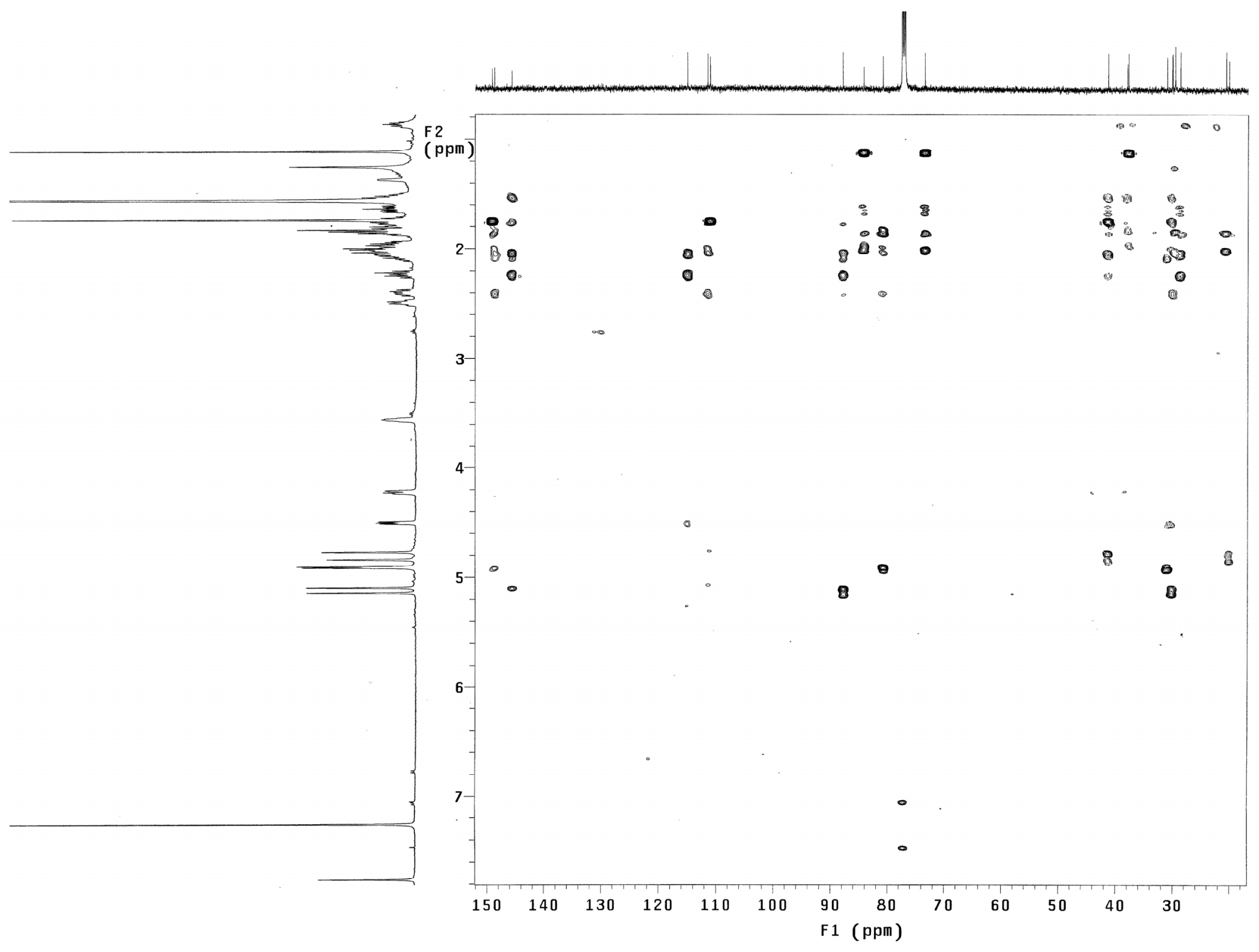

Figure S3-6. HMBC spectrum (500 MHz) of compound 3 in $\mathrm{CDCl}_{3}$. 


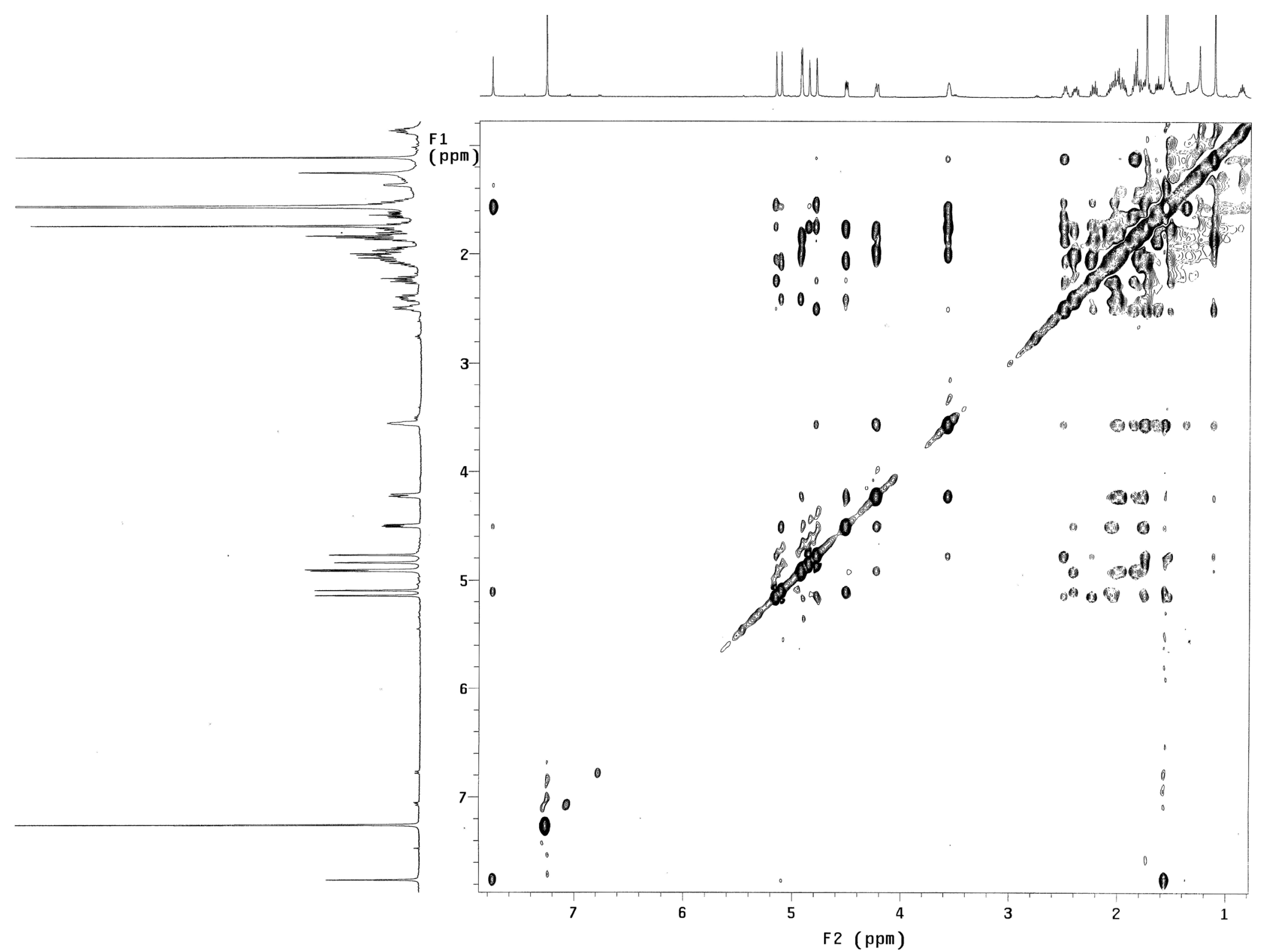

Figure S3-7. NOESY spectrum (500 MHz) of compound 3 in $\mathrm{CDCl}_{3}$. 


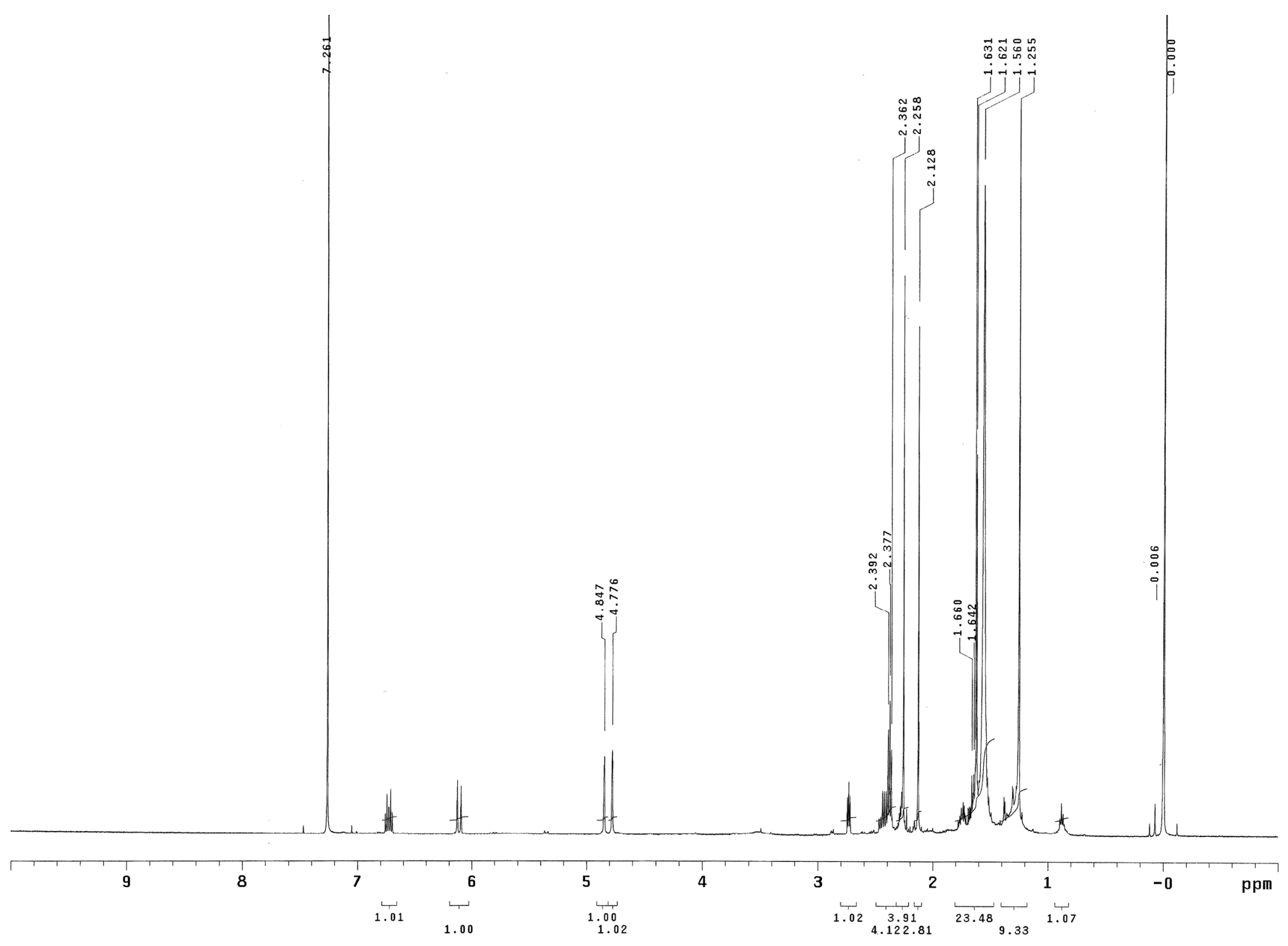

Figure S4-1. ${ }^{1} \mathrm{H}$ NMR spectrum $(500 \mathrm{MHz})$ of compound 4 in $\mathrm{CDCl}_{3}$. 


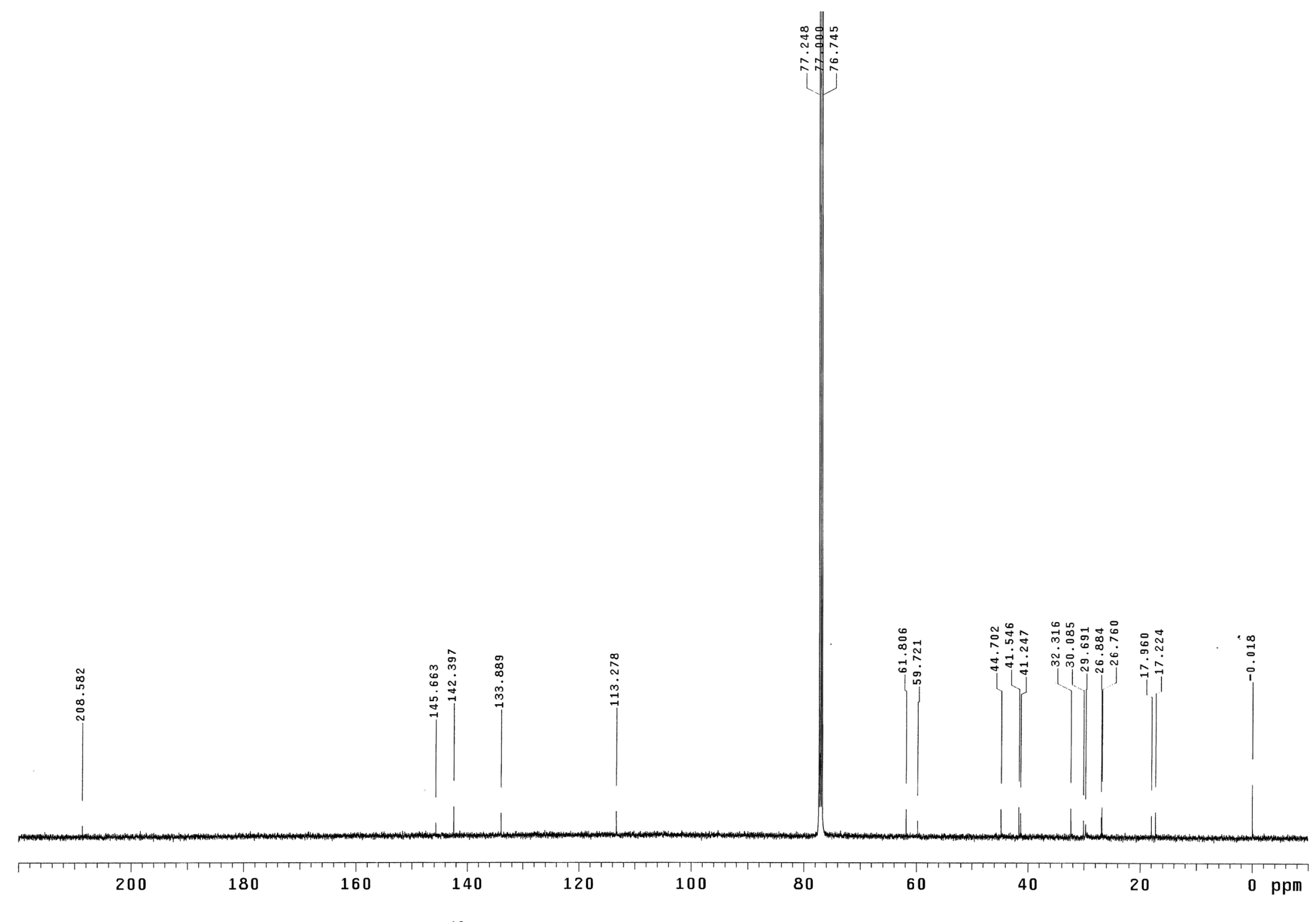

Figure S4-2. ${ }^{13} \mathrm{C}$ NMR spectrum $(125 \mathrm{MHz})$ of compound 4 in $\mathrm{CDCl}_{3}$. 
$\mathrm{CH} / \mathrm{CH} 3$ up, $\mathrm{CH} 2$ down

Wwatw

$\mathrm{CH}$ carbons

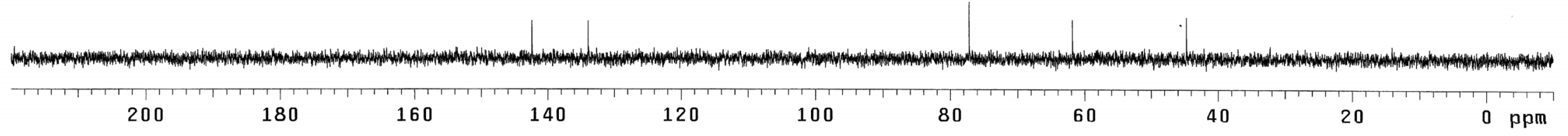

Figure S4-3. DEPT spectra (125 MHz) of compound 4 in $\mathrm{CDCl}_{3}$. 


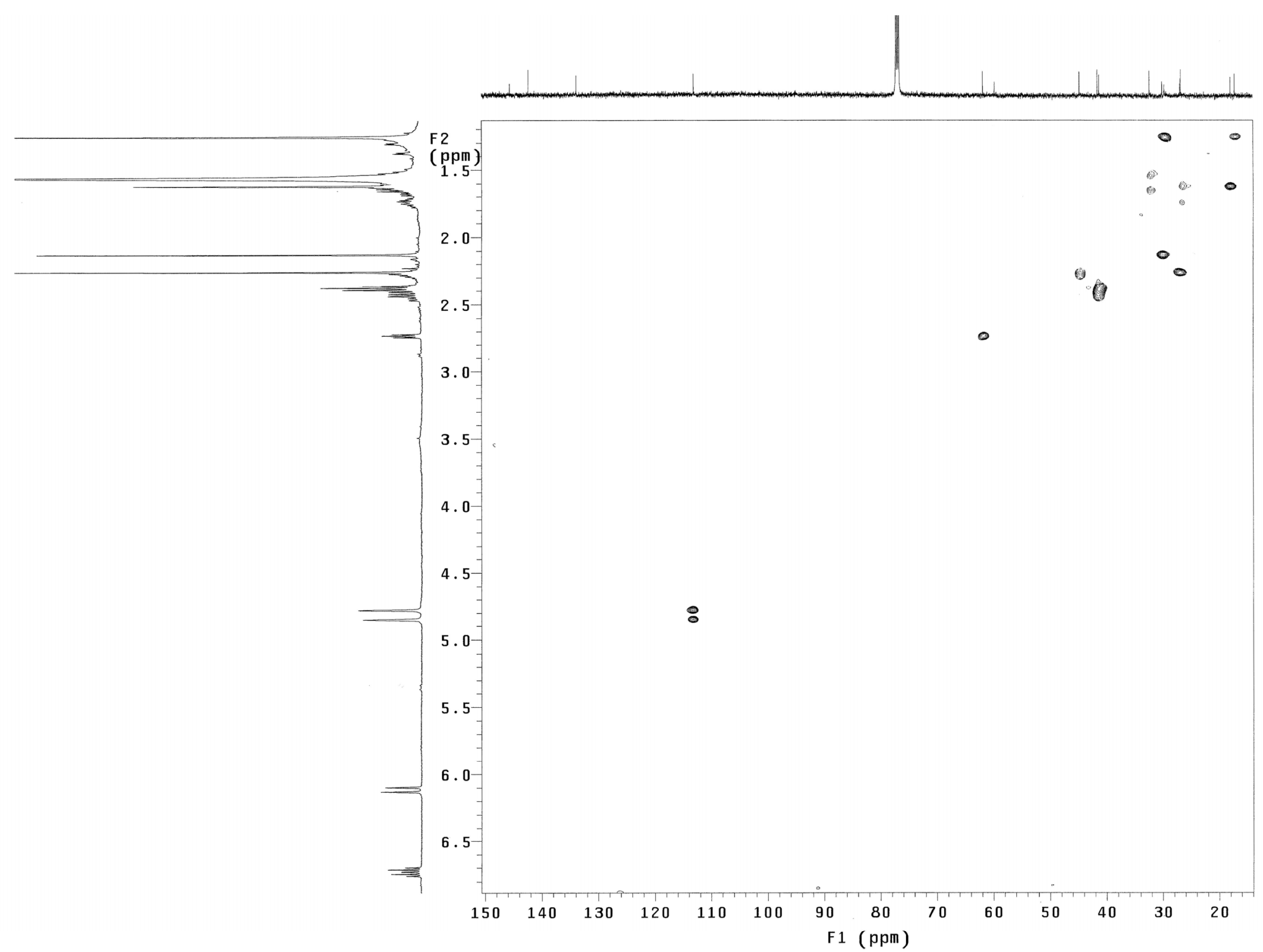

Figure S4-4. HSQC spectrum (500 MHz) of compound 4 in $\mathrm{CDCl}_{3}$. 


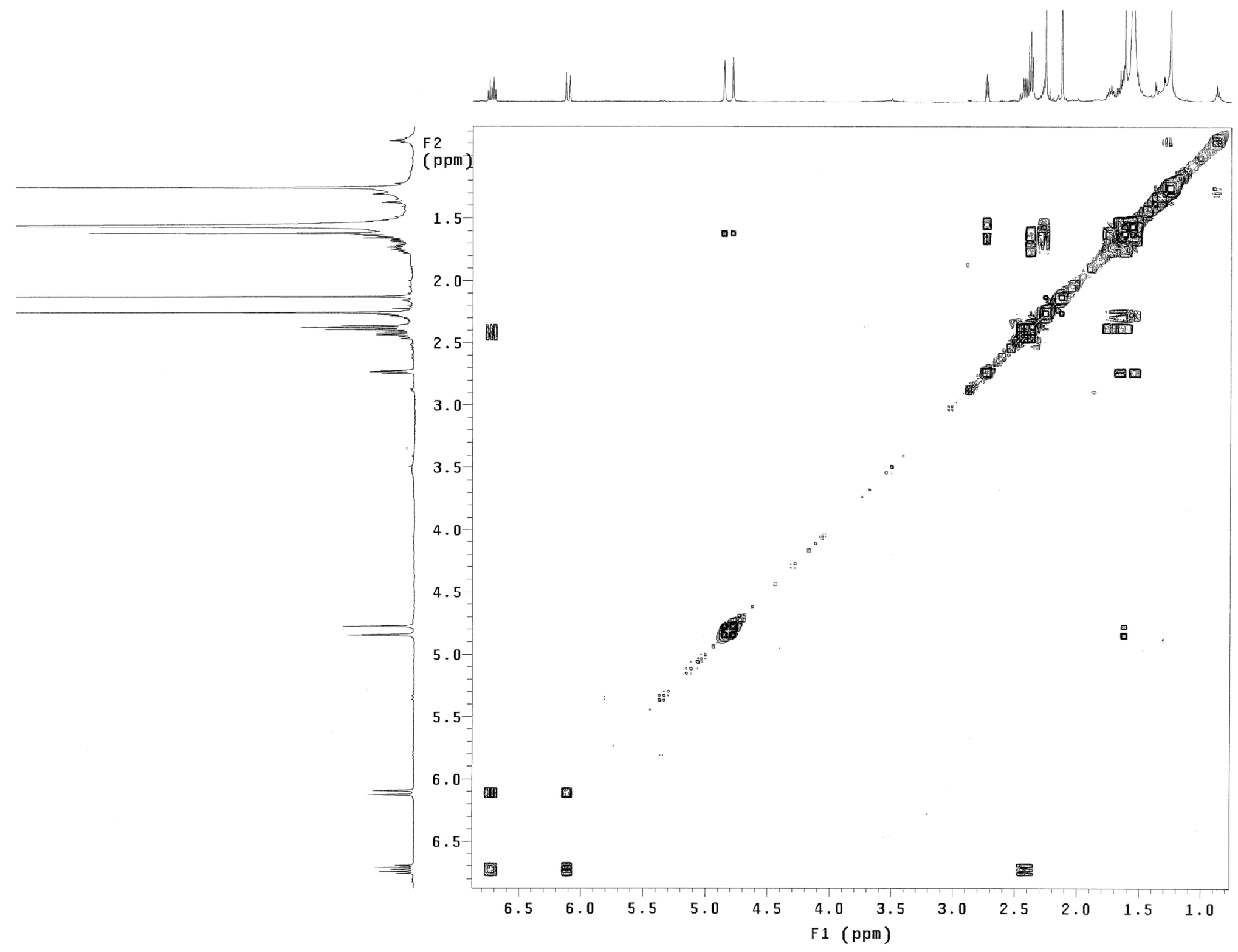

Figure S4-5. COSY spectrum (500 MHz) of compound 4 in $\mathrm{CDCl}_{3}$. 


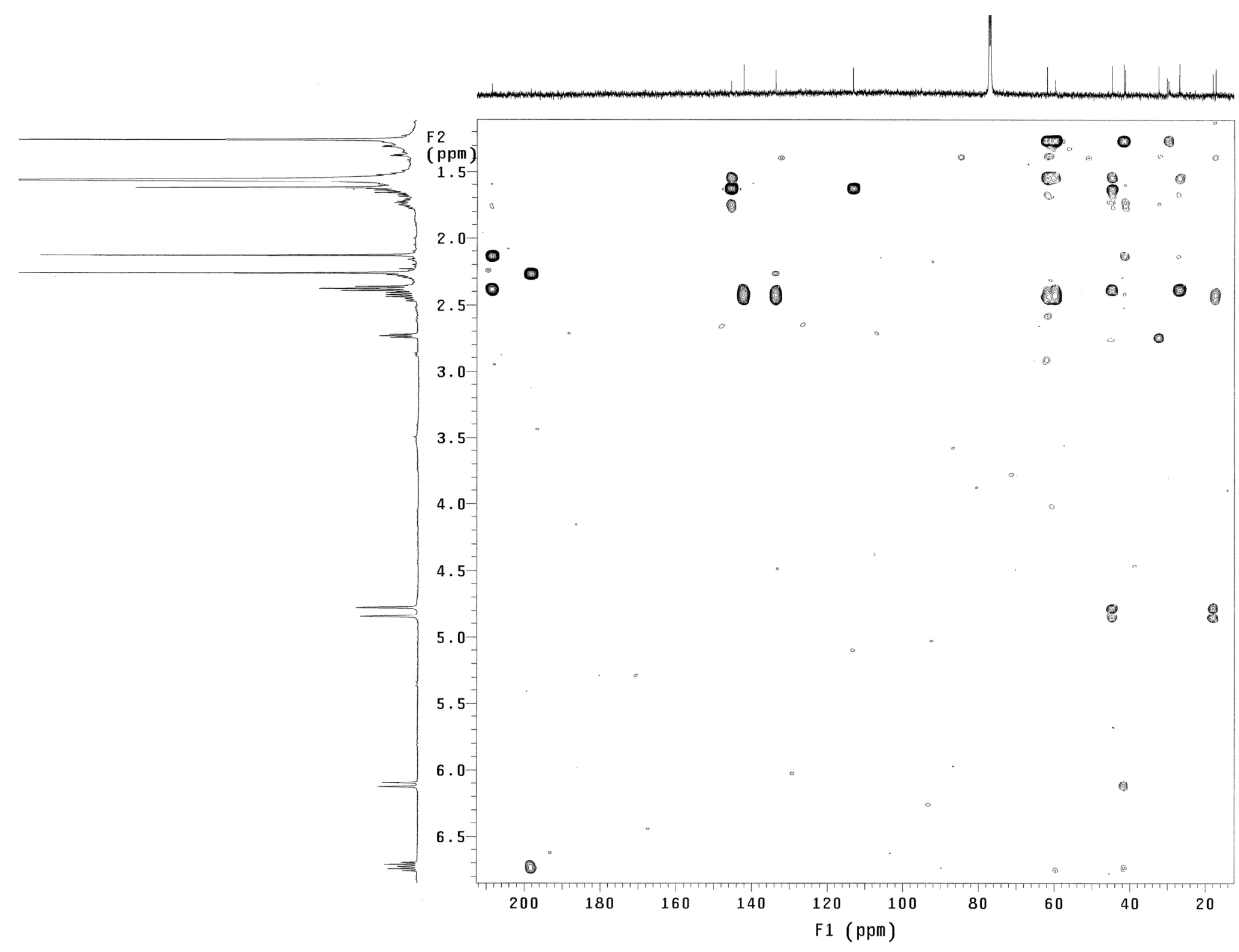

Figure S4-6. HMBC spectrum (500 MHz) of compound 4 in $\mathrm{CDCl}_{3}$. 


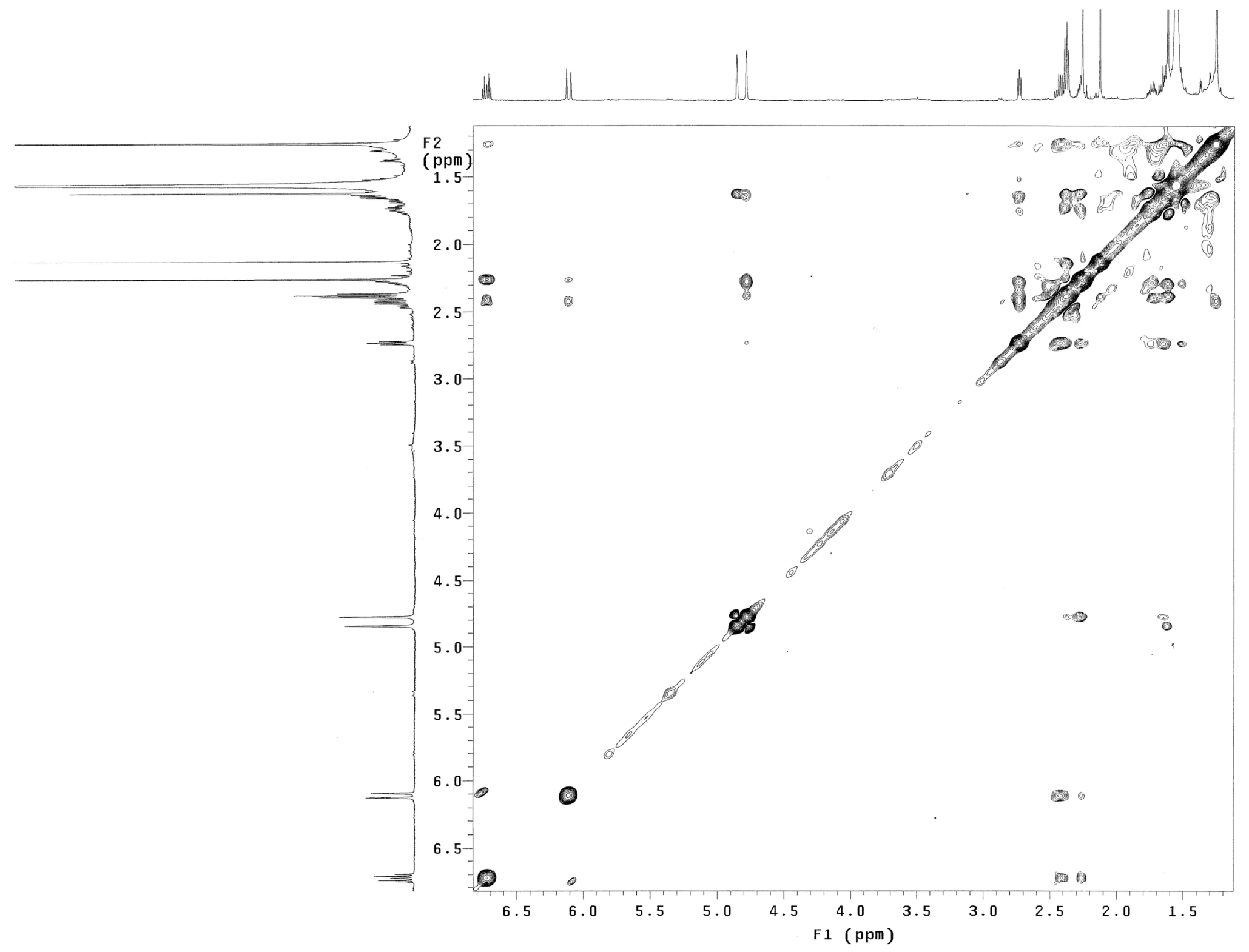

Figure S4-7. NOESY spectrum (500 MHz) of compound 4 in $\mathrm{CDCl}_{3}$. 
Table S5-1. ${ }^{1} \mathrm{H}$ and ${ }^{13} \mathrm{C}$ NMR spectroscopic data of $\mathbf{6}$.

\begin{tabular}{|c|c|c|c|c|}
\hline position & $\delta_{C}{ }^{a}$, type & $\delta_{\mathrm{C}}{ }^{b}$, type & $\delta_{\mathrm{H}}{ }^{c}$, mult $(J$ in $\mathrm{Hz})$ & $\delta_{\mathrm{H}}^{d}$, mult $(J$ in $\mathrm{Hz})$ \\
\hline 1 & $41.5, \mathrm{CH}^{e}$ & $41.5, \mathrm{CH}$ & 2.63, dddd $(12.8,12.0,7.2,5.2)$ & 2.85, dddd $(12.8,12.0,7.2,5.2)$ \\
\hline $2 \beta$ & $42.0, \mathrm{CH}_{2}$ & $43.4, \mathrm{CH}_{2}$ & $2.31, \mathrm{dd}(12.0,7.2)$ & $2.35, \mathrm{dd}(12.0,7.2)$ \\
\hline $2 \alpha$ & & & $1.68, \mathrm{dd}(12.0,12.0)$ & $1.82, \mathrm{dd}(12.0,12.0)$ \\
\hline 3 & 106.1, C & $105.9, \mathrm{C}$ & & \\
\hline $4 \beta$ & $40.9, \mathrm{CH}_{2}$ & 39.6, $\mathrm{CH}_{2}$ & $2.08, \mathrm{~d}(12.0)$ & $2.35, \mathrm{~m}$ \\
\hline $4 \alpha$ & & & $1.68, \mathrm{dd}(12.0,12.0)$ & $1.84, \mathrm{dd}(12.0,12.0)$ \\
\hline 5 & $75.7, \mathrm{CH}$ & $76.1, \mathrm{CH}$ & $4.04, \mathrm{~d}(12.0)$ & $4.32, \mathrm{~d}(12.0)$ \\
\hline 6 & 214.6, C & $212.8, \mathrm{C}$ & & \\
\hline $7 \beta$ & $50.5, \mathrm{CH}_{2}$ & $51.2, \mathrm{CH}_{2}$ & $2.42, \mathrm{~d}(17.6)$ & $2.48, \mathrm{~d}(17.6)$ \\
\hline $7 \alpha$ & & & $2.42, \mathrm{~d}(17.6)$ & $2.26, \mathrm{~d}(17.6)$ \\
\hline 8 & 78.0, C & 78.4, C & & \\
\hline $9 \beta$ & $40.5, \mathrm{CH}_{2}$ & $41.6, \mathrm{CH}_{2}$ & $2.47, \mathrm{~m}$ & $2.63, \mathrm{dd}(16.0,6.4)$ \\
\hline $9 \alpha$ & & & $2.13, \mathrm{~m}$ & $2.13, \mathrm{~d}(16.0)$ \\
\hline 10 & $78.2, \mathrm{CH}$ & $78.1, \mathrm{CH}$ & $4.83, \mathrm{~d}(6.4)$ & $4.86, \mathrm{~d}(6.4)$ \\
\hline 11 & $66.2, \mathrm{CH}$ & $67.2, \mathrm{CH}$ & $4.69, \mathrm{~s}$ & $4.35, \mathrm{~s}$ \\
\hline 12 & $61.4, \mathrm{C}$ & $61.7, \mathrm{C}$ & & \\
\hline 13 & $67.4, \mathrm{CH}$ & $68.9, \mathrm{CH}$ & 3.37, dd $(6.0,5.2)$ & $3.61, \mathrm{dd}(6.0,5.2)$ \\
\hline $14 \beta$ & $30.7, \mathrm{CH}_{2}$ & $30.6, \mathrm{CH}_{2}$ & $2.16, \mathrm{~m}$ & $2.36, \mathrm{~m}$ \\
\hline $14 \alpha$ & & & $1.40, \operatorname{ddd}(12.8,12.8,5.2)$ & 1.57, ddd $(12.8,12.8,5.2)$ \\
\hline 15 & $88.1, \mathrm{C}$ & $88.8, \mathrm{C}$ & & \\
\hline $16 \beta$ & $47.8, \mathrm{CH}_{2}$ & $45.6, \mathrm{CH}_{2}$ & $3.96, \mathrm{~d}(12.0)$ & $4.04, \mathrm{~d}(12.0)$ \\
\hline $16 \alpha$ & & & $3.52, \mathrm{~d}(12.0)$ & $3.66, \mathrm{~d}(12.0)$ \\
\hline 17 & $170.7, \mathrm{C}$ & $172.9, \mathrm{C}$ & & \\
\hline 18 & $23.9, \mathrm{CH}_{3}$ & $24.8, \mathrm{CH}_{3}$ & $1.33, \mathrm{~s}$ & $1.45, \mathrm{~s}$ \\
\hline 19 & $169.5, \mathrm{C}$ & $169.0, \mathrm{C}$ & & \\
\hline $\mathrm{OMe}$ & $52.2, \mathrm{CH}_{3}$ & $53.3, \mathrm{CH}_{3}$ & $3.73, \mathrm{~s}$ & $3.86, \mathrm{~s}$ \\
\hline
\end{tabular}

${ }^{a}$ Spectra recorded at $100 \mathrm{MHz}$ in DMSO- $d_{6} \cdot{ }^{b}$ Spectra recorded at $100 \mathrm{MHz}$ in $\mathrm{CDCl}_{3} .{ }^{c}$ Spectra recorded at $400 \mathrm{MHz}$ in DMSO- $d_{6} .{ }^{d}$ Spectra recorded at $400 \mathrm{MHz}$ in $\mathrm{CDCl}_{3} .{ }^{e}$ Attached protons were deduced by DEPT experiments. 


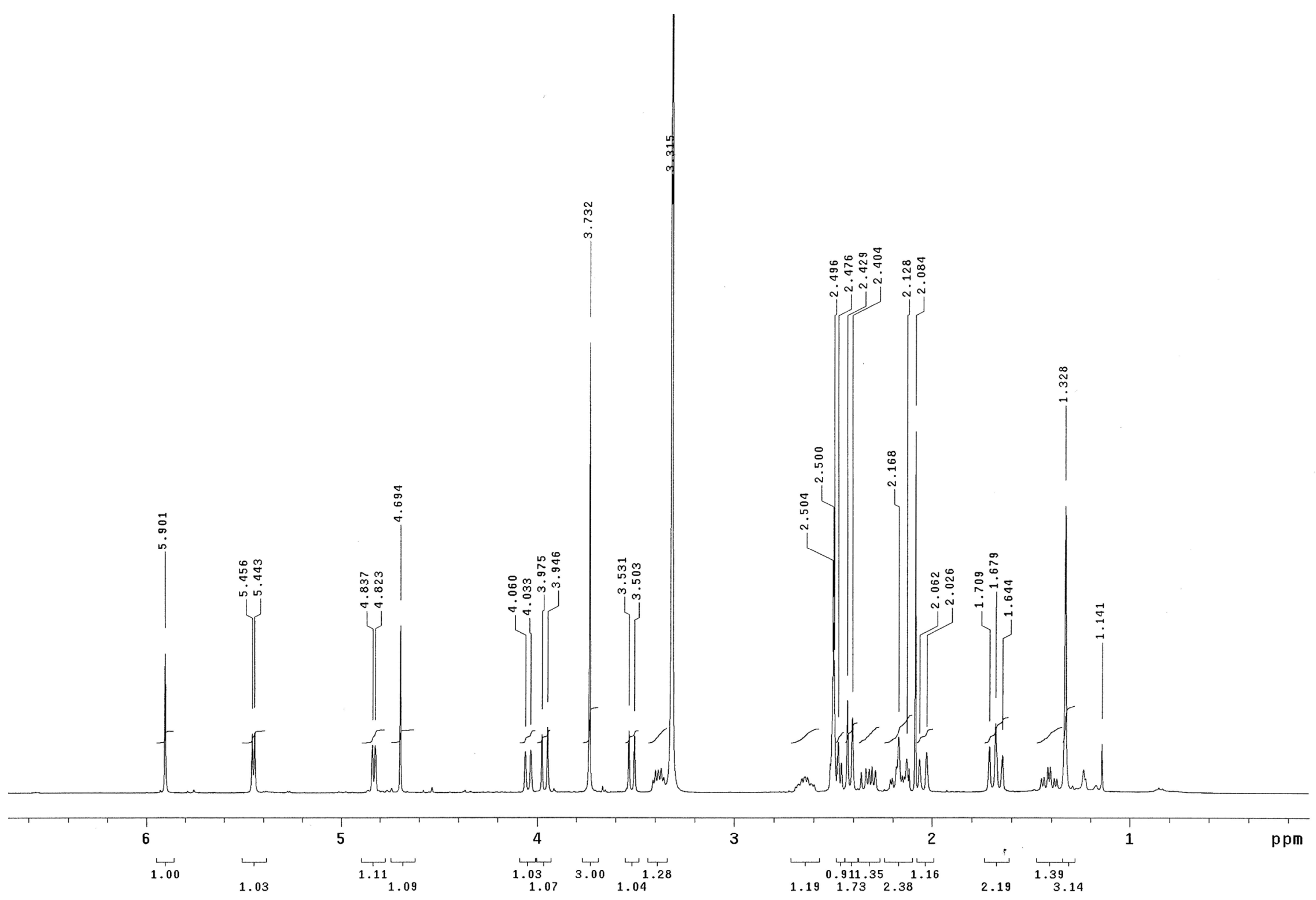

Figure S5-2. ${ }^{1} \mathrm{H}$ NMR spectrum $(400 \mathrm{MHz})$ of compound 6 in DMSO- $d_{6}$. 


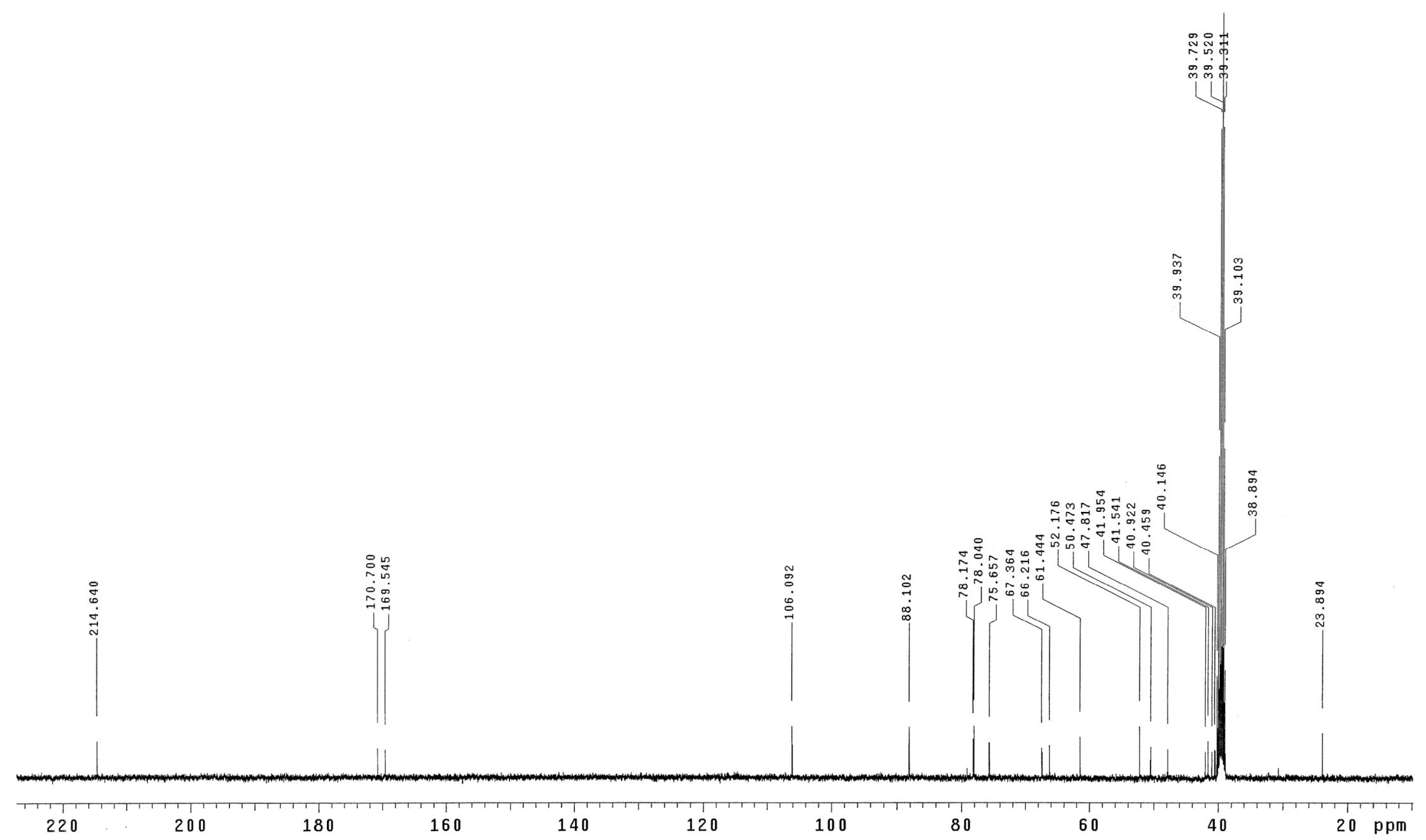

Figure S5-3. ${ }^{13} \mathrm{C}$ NMR spectrum $(100 \mathrm{MHz})$ of compound 6 in DMSO- $d_{6}$. 


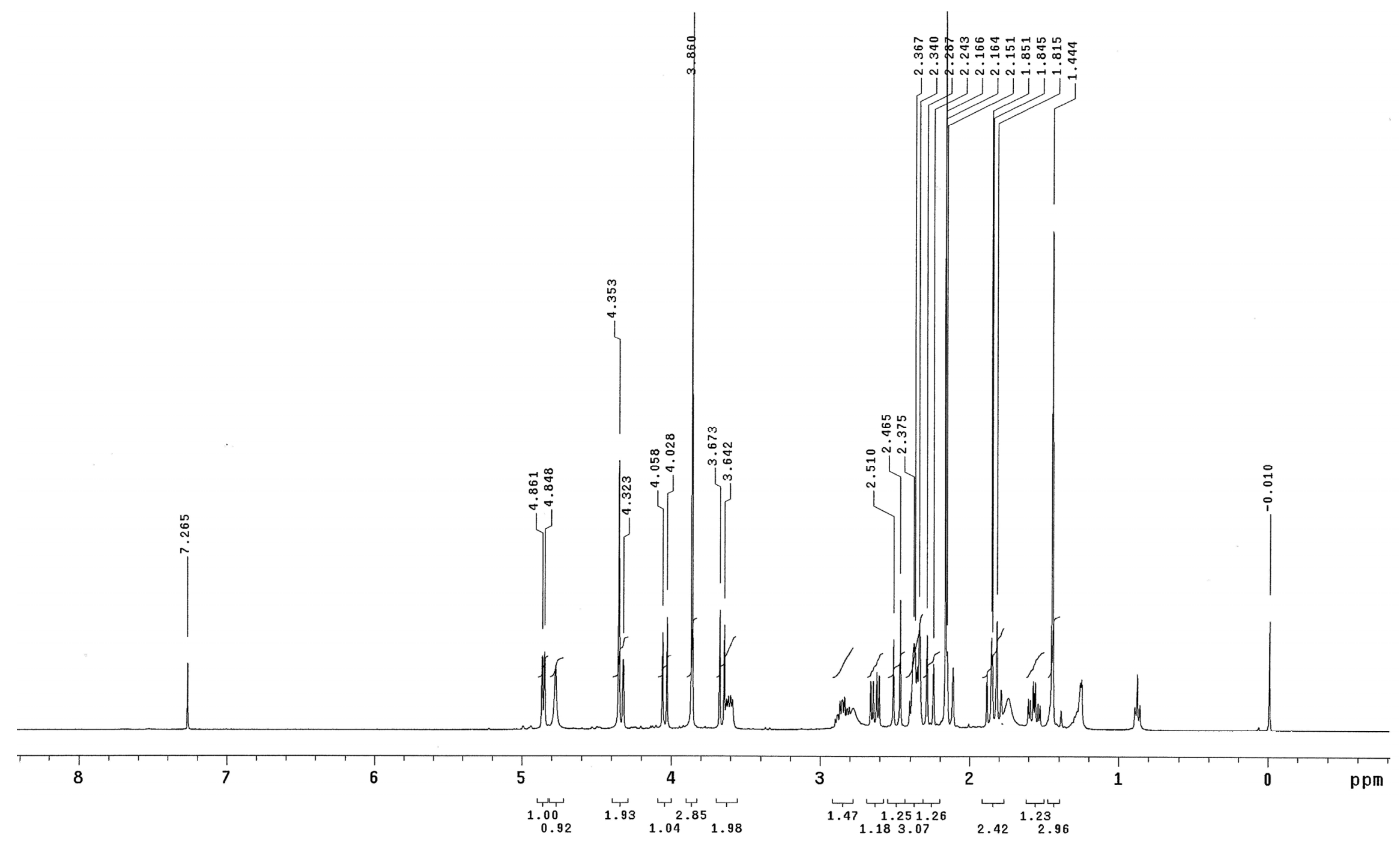

Figure S5-4. ${ }^{1} \mathrm{H}$ NMR spectrum $(400 \mathrm{MHz})$ of compound 6 in $\mathrm{CDCl}_{3}$. 


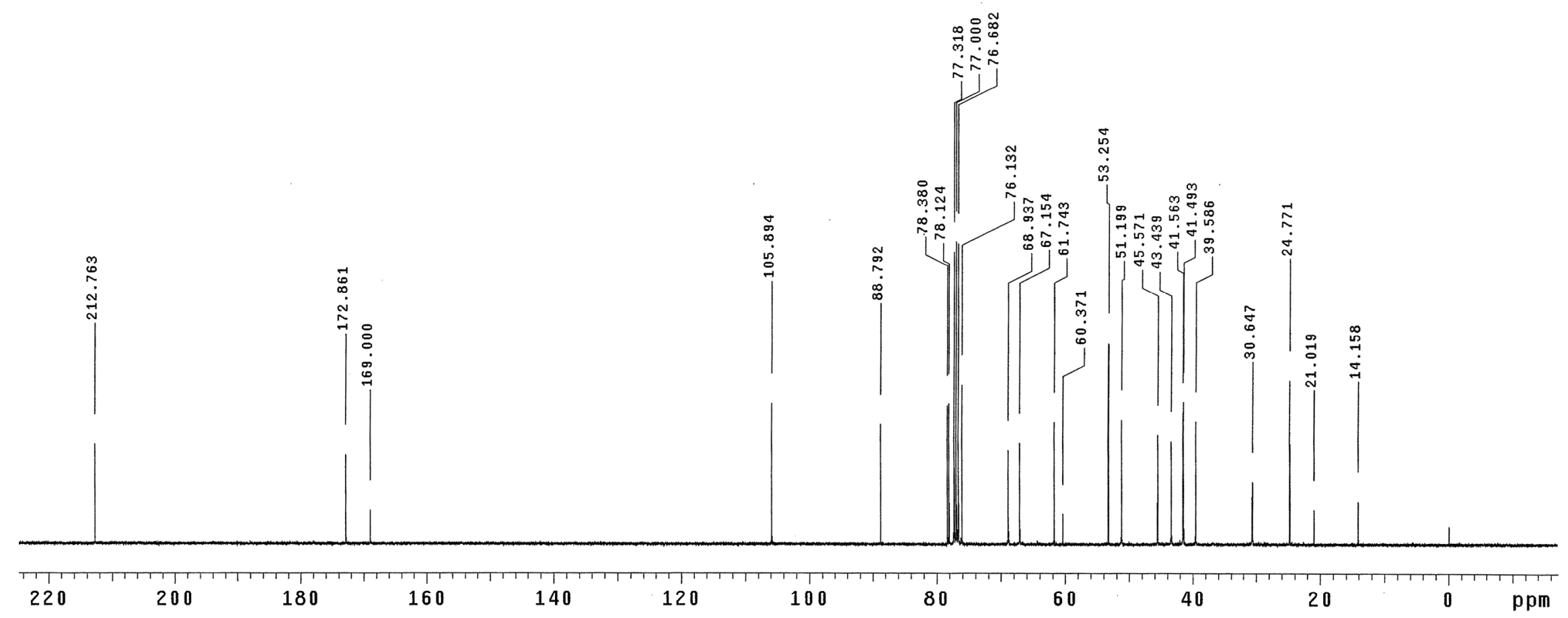

Figure S5-5. ${ }^{13} \mathrm{C}$ NMR spectrum $(100 \mathrm{MHz})$ of compound 6 in $\mathrm{CDCl}_{3}$. 


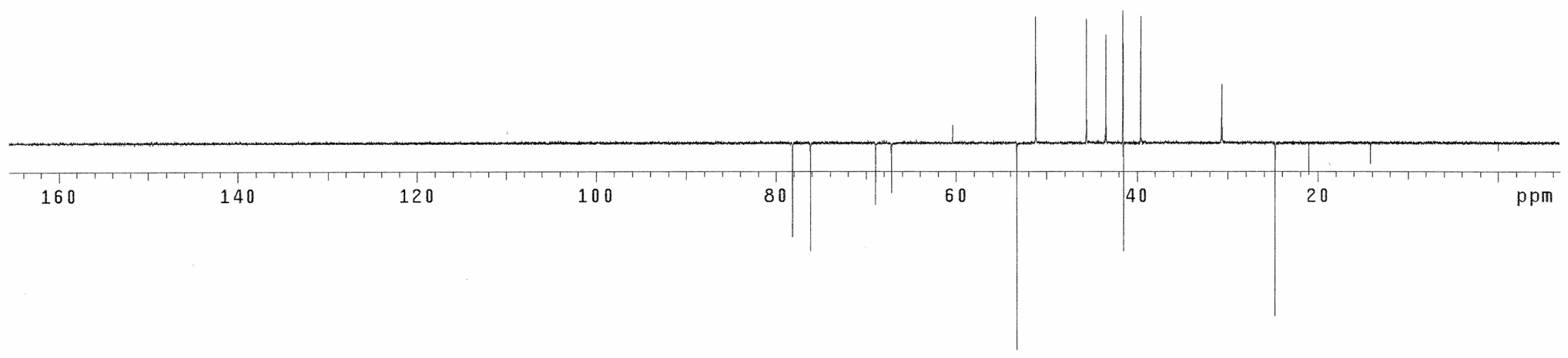

Figure S5-6. DEPT spectra (100 MHz) of compound 6 in $\mathrm{CDCl}_{3}$. 


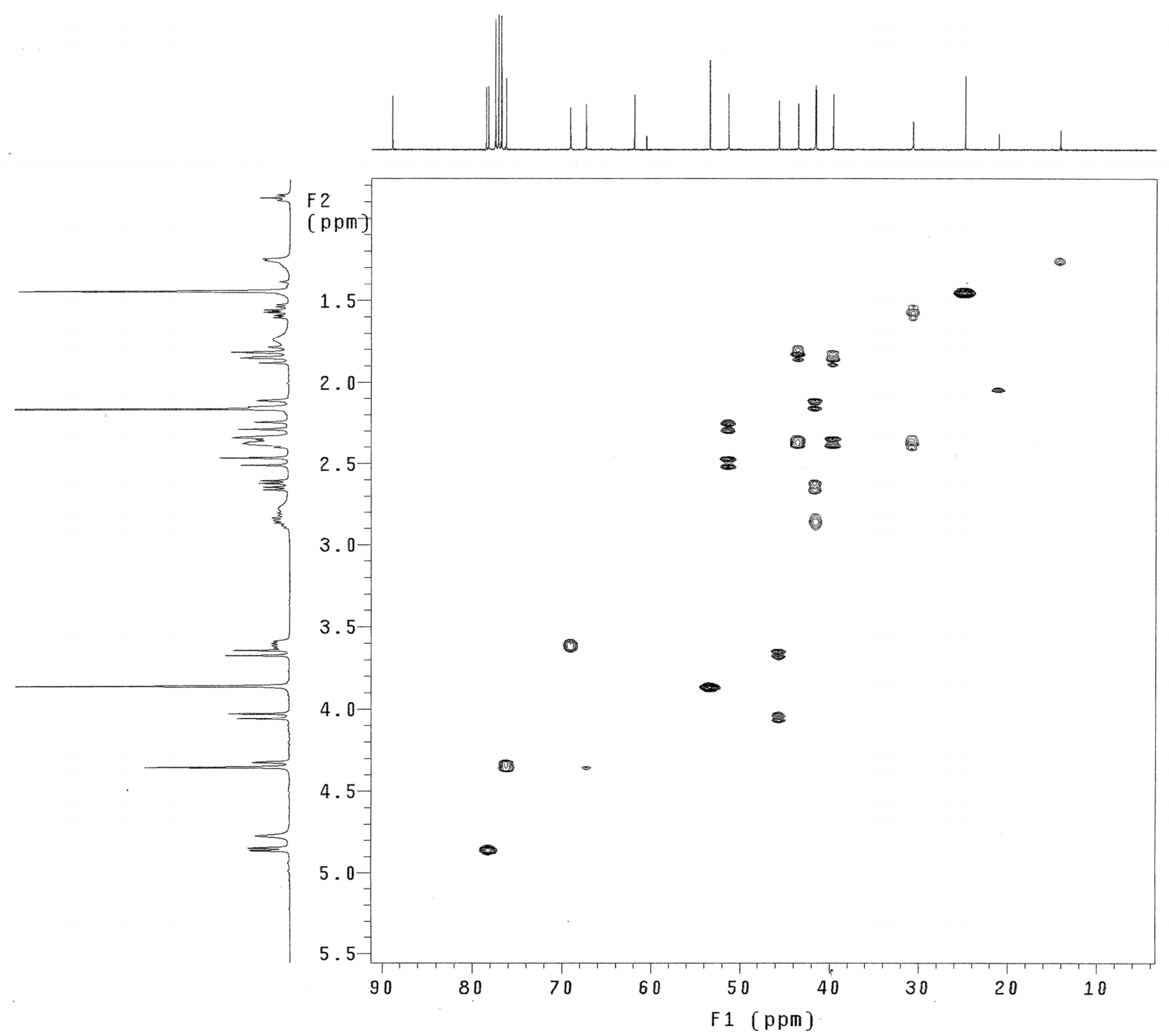

Figure S5-7. HSQC spectrum (400 MHz) of compound 6 in $\mathrm{CDCl}_{3}$. 


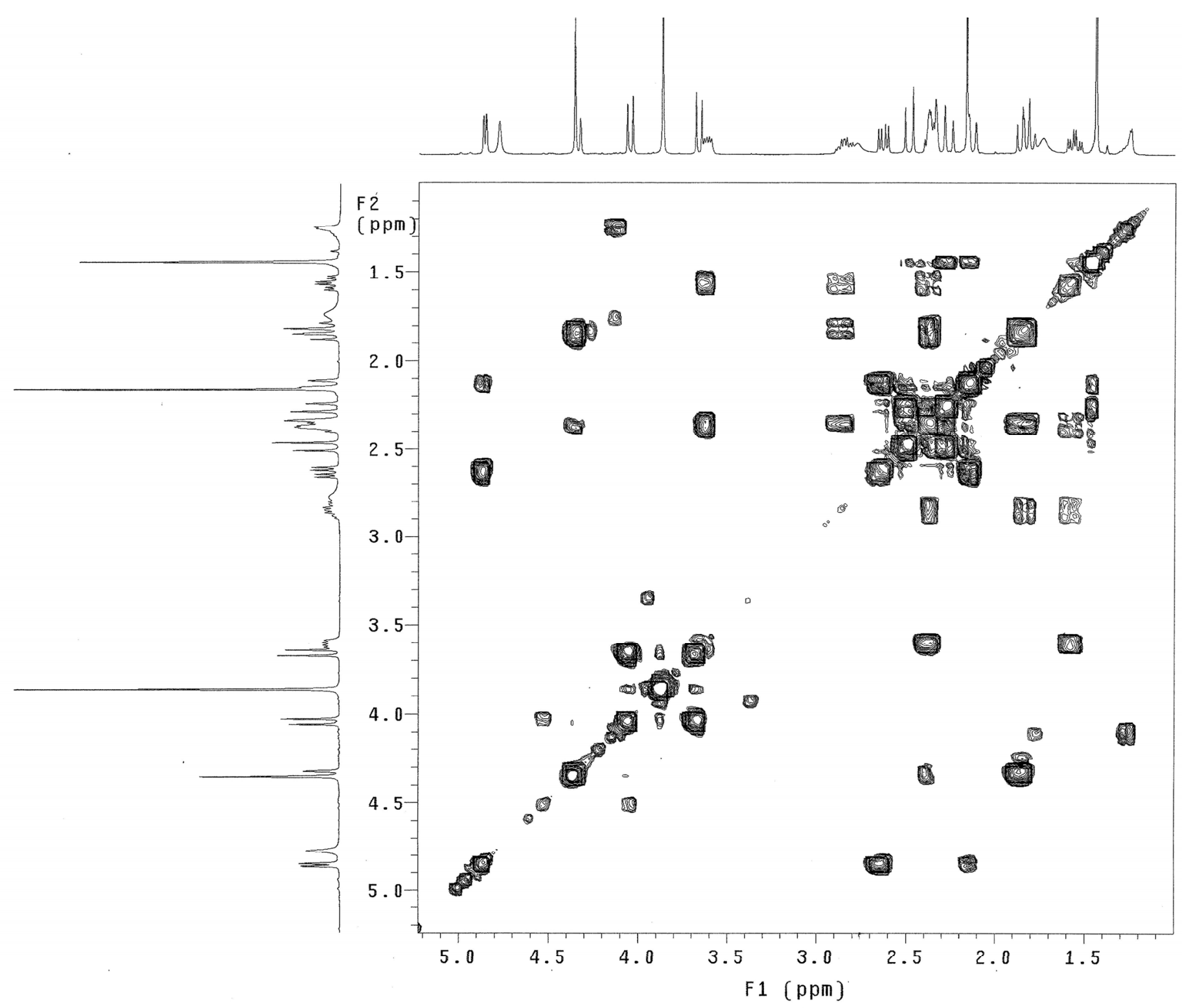

Figure S5-8. COSY spectrum $(400 \mathrm{MHz})$ of compound 6 in $\mathrm{CDCl}_{3}$. 


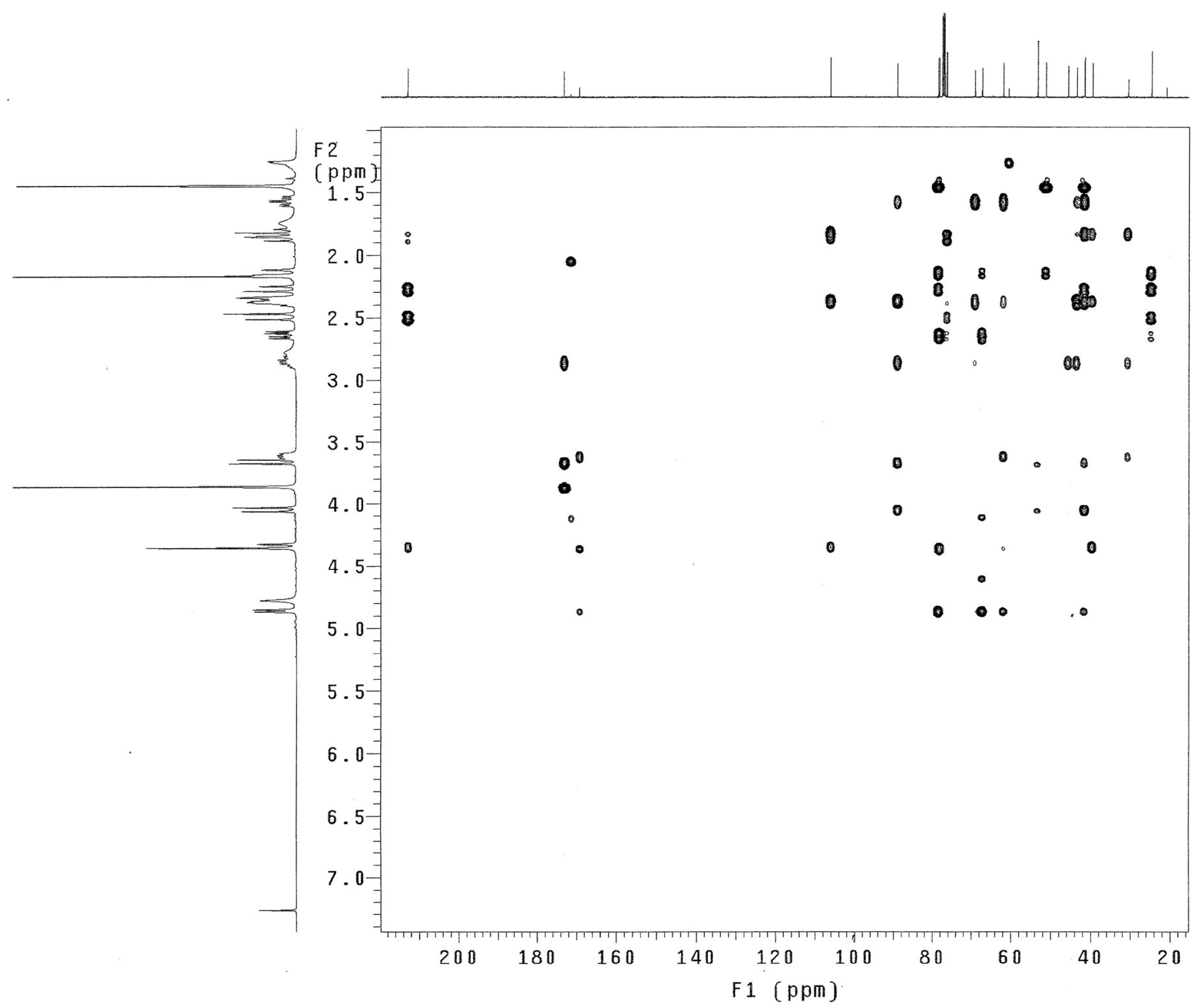

Figure S5-9. HMBC spectrum (400 MHz) of compound 6 in $\mathrm{CDCl}_{3}$. 


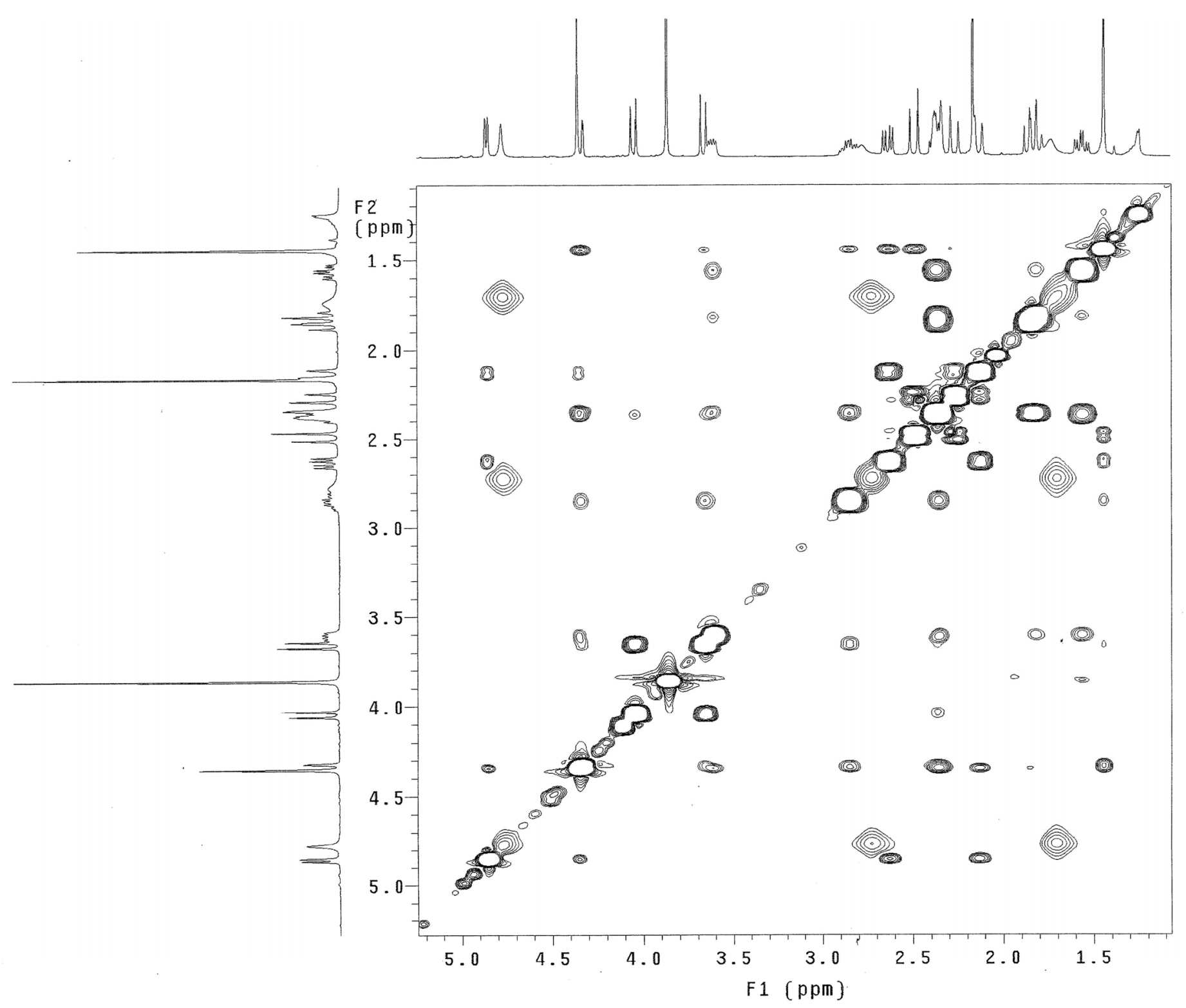

Figure S5-10. NOESY spectrum (400 MHz) of compound 6 in $\mathrm{CDCl}_{3}$. 
Table S6. Cytotoxicities of compounds 3,4 and 8 .

\begin{tabular}{cccc}
\hline & \multicolumn{3}{c}{ Cell lines $\mathrm{IC}_{50}(\mu \mathrm{M})$} \\
\cline { 2 - 4 } compound & K-562 & CCRF-CEM & MOLT-4 \\
\hline $\mathbf{3}$ & $9.2 \pm 3.3$ & $-^{a}$ & - \\
$\mathbf{4}$ & $8.6 \pm 1.1$ & - & $9.7 \pm 2.9$ \\
$\mathbf{8}$ & - & $6.3 \pm 1.5$ & $9.7 \pm 3.6$ \\
5-Fluorouracil & $33 \pm 9$ & $17 \pm 5$ & $6.9 \pm 1.5$ \\
\hline a-: Compound is considered inactive with $\mathrm{IC}_{50}>10 \mu \mathrm{M}$. The values are \\
mean \pm SEM. $(\mathrm{n}=3)$.
\end{tabular}

